\title{
A seismic-driven 3D model of rock mechanical facies: an example from the Asmari Reservoir, SW Iran
}

\author{
Sajjad Gharechelou ${ }^{\mathrm{a}}$, Sepideh Sohrabi ${ }^{\mathrm{a}}$, Ali Kadkhodaie-Illkhchi ${ }^{\mathrm{b}, \mathrm{e} *}$, Hossain Rahimpour-Bonab $^{\mathrm{a}}$, \\ Javad Honarmand', Gholamhossein Montazeri ${ }^{\mathrm{d}}$ \\ ${ }^{\text {aS }}$ chool of Geology, College of Science, University of Tehran, Tehran, Iran \\ (sgharechelo@ut.ac.ir; sohrabi_sepideh@alumni.ut.ac.ir; hrahimpor@gmail.com) \\ b* Department of Geology, University of Tabriz, Tabriz, Iran (kadkhodaie_ali@tabrizu.ac.ir) \\ 'Research Institute of Petroleum Industry, Petroleum Geology Dept., Tehran, Iran (honarmandj@gmail.com) \\ ${ }^{\mathrm{d}}$ Head of petroleum engineering at ICOFC (montazeri_gh@yahoo.com) \\ eDepartment of Petroleum Engineering, Curtin University, Western Australia (ali.kadkhodaie@curtin.edu.au)
}

\section{Abstract}

Asmari Formation is one of the most prolific and important hydrocarbon reservoirs in Iran. This formation in the Cheshmeh-Khosh oilfield shows mixed carbonate-siliciclastic lithology and its elastic modulus changes are correlatable with facies changes. To address these changes, we investigated the relation between sedimentary environment (facies) and texture with various elastic moduli. The Young's modulus shows higher correlation with the facies changes.

Data from three wells are analyzed and used for the construction of rock mechanical facies. Based on elastic properties, facies and texture changes as well as petrophysical characteristics seven rock mechanical facies (RMFs) are recognized in the studied formation. To predict RMFs at inter-well spaces more efficiently and capturing the lateral formation property variationsa 3D rock mechanical facies model is constructed based on seismic attributes. In this method, RMFs are correlatable between the studied wells and mappable by seismic attribute in the field scale. Finally, the distribution of RMFs and their related properties is investigated in the studied field.

Key words: Rock mechanic, Young’s modulus, facies, seismic attribute, Asmari reservoir 


\section{Introduction}

The elastic properties of reservoir rocks are key factors in reservoir rock characterization. Understanding these properties can decrease development costs and risks involved in optimizing field development plans, refining drilling program and making reasonable predictions of production rate. Furthermore, seismic reflectivity modeling, interpreting seismic data and evaluation of reservoir compaction are some of the most important aspects of determination of rock elastic properties (Ghazvinian et al., 2012; Brahma and Sircar, 2014).

The main reservoir rock in the Zagros area, southwest Iran, is the Asmari Formation which hosts numerous giant and supergiant hydrocarbon reserves. The studied field, which is located in the Dezful Embayment, is composed of mixed carbonate-siliciclastic lithology. Here, the upper part of the unit (Miocene) is dominated by carbonate but the lower part (Oligocene) is mainly composed of siliciclastics. Facies changes in this formation are very sharp and considerable.

A number of authors including Shakoor and Brown (1996), Topal and Doyuran (1997), Bell et al. (1999), Chatterjee and Mukhopadhyay (2001), Jeng et al. (2004) Hussain et al. (2006), Williams et al. (2012) and Fournier et al. (2014) have discussed the relationships between sedimentological characteristics with the

geomechanical properties of reservoir rocks. Largely, several geological factors including porosity, grain size, mineralogy, and cement control the rock elastic properties (Hussain et al., 2006). These parameters are strongly controlled by the facies texture and overprinted diagenetic features.

Generally, description of formation properties and rock mechanical parameters with higher accuracy results in reasonable wellbore stability predictions for any locations in a field prior to drilling. Actually, a good estimation of formation elastic properties will lead to an accurate stress analysis that could prevent future financial losses (Dehghani et al., 2014). The present study evaluates the rock elastic properties based on Young's modulus and facies textures in the Asmari Formation, aiming to define the rock mechanical 
facies (RMF). Accordingly, the relationships between changes in the facies and elastic properties are investigated. Thus, the main objective of the present study is to evaluate rock elastic changes (Young's modulus) in the framework of depositional environments (facies) and their related characteristics. By creating a relation between facies and elastic modulus it is possible to determine the elastic modulus continuously along the wellbores and formulate it in a geologic framework. Furthermore, unlike the previous works, in this method results are not limited to the cored interval and cover all intervals in the interested unit. Also by this approach, the results would be useful for inter-wells correlation and extending the results from the well- scale to the field-scale.

The idea of using multiple seismic attributes to predict log properties was first proposed by Schultz, Ronen, Hattori and Corbett in a series of three articles in the Leading Edge and Hampson et al 2001. Our study extends this concept to rock mechanical properties. The logic behind relies on this fact that there is an inverse relation between porosity and acoustic impedance. As rock strength is dependent on porosity so it is expected to find relations between geomechanical facies and seismic attributes. This enables us for full-field rock mechanic simulation of the studied reservoir and to aid understanding the reservoir operational practices within different segments of the field. To achieve such goals, it is important to define the RMFs and link them to seismic attributes.

\section{Geological setting}

The Asmari Formation is the youngest and most prolific reservoir horizon in SW Iran. This formation in the Zagros fold belt is diachronous as its base aged the Early Rupelian in a NW-SE trending basin and was followed in mid-Burdigalian time by the deposition of evaporates and marls of the Gachsaran Formation (Motiei, 1993). This productive fractured reservoir produces more than $80 \%$ of total Iranian crude oil. The Oligo-Miocene cyclic successions of South West Iran (Asmari Formation) in Cheshmeh-Khoshoilfield are composed of mixed carbonate-siliciclastic rocks. 
The studied field is located in the southwest of Zagros Mountains and in the northwestern edge of the Dezful Embayment (figure 1). The Dezful Embayment structural zone is characterized by a low elevation and few outcrops of the Asmari Formation and it contains most of the Iranian oilfield (Cenozoic). This area in the southwest Iran is one of the most prolific oil provinces in the Middle East (e.g. Haynes and McQuillan, 1974; Wennberg et al., 2006). This structural embayment is located in the central Zagros foldthrust belt, SW Iran, a belt locating in the Alpine-Himalayan orogeny and is the result of the Tertiary continental collision between the Arabian Plate and Iranian blocks (Berberian and King, 1981).

In the studied field, the Asmari Formation shows variable lithological and facies characteristics and is generally composed of limestone, dolomite, anhydrite and sandstone. Such important lithological variations led to observed temporal and special heterogeneity in the elastic properties and reservoir quality. The upper and lower contacts of the Asmari with its overlaying the Gachsaran (anhydrite cap rock) and underlying Pabdeh formations (shale and marl source rock) are unconformable.

\section{Materials and methods}

In order to determine the controlling geological parameters on the elastic properties, the Asmari reservoir at three wells of the Cheshmeh-Khosh oilfield is investigated. The main available data in this study include thin sections from cores, well logs, check-shot data, formation tops and 3D post stack seismic data.

High resolution petrographic studies along with image analysis technique were employed to determine rock components (grains, particles and mud or cement), texture (e.g. Dunham, 1962) and finally depositional facies (Wilson, 1975; Buxton and Pedley, 1989; Pettijohn et al., 1987; Flugel, 1982 and 2010). Accordingly, a detailed petrographic analysis of 1550 thin sections carried out to investigate the various

textures, facies variation and distribution along with pore typing in both carbonate and clastic intervals of the Asmari Formation.

The elastic properties (i.e., dynamic Young's modulus) were calculated from wireline logs continuously along the wellbore. Observed disparities in the determined Young's modulus are correlated and related to 
the inconsistency in the facies and their textures. After determining the rock elastic parameters for each facies, RMFs are defined and mapped in the field scale. For this purpose, 3D seismic volume is used to map the RMFs distribution throughout the field. The seismic data in this field includes 773 in-lines and 256 cross-lines in the surveyed area of about $130 \mathrm{Km}^{2}$.

\section{Facies description}

The Asmari Formation that deposited on a tropical ramp covering SW Iran in Oligo-Miocene (Henson, 1951; Dunnington, 1958, 1967; James and Wynd, 1965) shows a high variability from lithological point of view. Accordingly, its main lithology in the Dezful Embayment and the studied field comprises carbonate, mixed carbonate-evaporate and mixed carbonate-siliciclastic rocks (Van Buchem et al., 2010).

Facies analysis of the Asmari Formation resulted in the recognition of 12 microfacies, which can be grouped into five facies associations in the carbonate intervals and 5 sedimentary facies in the siliciclastic interval (figure 2). A mixed carbonate-siliciclastic environment model is proposed for the Asmari Formation in the studied oilfield (Honarmand, 2013). The carbonate interval (Aquitanian and Burdigalian) deposited in a homoclinal ramp. The siliciclastic interval (Rupelian and Chattian) of this formation formed in Coastal plain to terrestrial/fluvial environment; distal deltaic and subtidal environment and offshore marine to basin (Van Buchem et al., 2010; Honarmand, 2013). Seemingly, the latter part is correlated with Ghar Formation in Kuwait whose clastic inputs is believed to have been derived from the pre-rift uplift of the Red Sea to the west (Alsharhan and Nairn, 1997). This formation sourced most sandstones where the exposed Arabian Shield shed large amounts of clastics onto the eastern Arabian plate (e.g. Sharland et al., 2001). Clastics mainly deposited during lowst and, whereas carbonate deposition dominated during highstands.

Based on detailed petrography and facies analysis using thin sections and core description, 12 microfacies types were identified for the Asmari Formation in the studied carbonate intervals (Table 1). Accordingly, they are classified into five main facies associations (belts) representing a Homoclinal ramp 
system. These facies associations include deep open marine (MF A), shallow open marine (MF B1 \& B2), barrier/shoal (MF C1, C2 \& C3), lagoon (MF D1, D2 \& D3) and intertidal (MF E1, E2 \& E3). This ramp depositional model corresponds to Eocene and Miocene ramp models published by Brandano and Corda(2002), Corda and Brandano(2003) (figure 2a, Table 1).

Thin-section study and core description of the clastic intervals resulted in identification of 5facies (F, G, H, I \& J). These facies from offshore to coastal plain respectively includes: Facies F: Bioturbated finegrained sandstone; Facies G: Conglomerate and coarse to medium-grained sandstone; Facies H: Shaly/silty sand; Facies I: well-sorted sandstone; Facies J: Sandstones along with shale/silt interlaminates (figure 2b). Figures 2 and 5 show rock texture and facies position of carbonate and clastic parts of the Asmari Formation in the studied wells.

\section{Rock mechanical facies}

The relationships between lithological and stratigraphical properties of the reservoir rocks and their mechanical characterizations have been investigated by British Petroleum (BP) in the 1990's (Williams et al., 2012). Understanding the reservoir rock mechanical behavior, beside their facies changes, could lead us in predicting complex reservoir properties, fracture susceptibility and diagnosis as well as calibration of static and dynamic flow properties. This understanding is important in the applied geomechanical purposes such as hydraulic fracturing design, analysis of wellbore stability and rock failure, determination of in situ stress, assessment of the response of reservoirs and surrounding rocks to changes in pore pressure and stress calculation of Young's modulus and Poisson's ratios (PR) (Brahma and Sircar, 2014). Rock elastic properties are directly linked to the lithology, pore type and elastic moduli of pore fluids (Zhang and Bentley, 2003). Moreover, facies type, texture and diagenetic imprints generally affect the rock elastic properties (Verwer et al., 2008; Brigaud et al., 2010; Fournier et al., 2011). It means that sedimentary environment and the subsequent diagenetic overprints control general physical and chemical properties of reservoir rock. 
In this study, rock mechanical properties are calculated by using log data (dynamic modulus) because these data are continuous along the wellbore and correlatable between wells. In addition, for reservoir characterization by seismic attributes, we need a continuous parameter along the wellbore (i.e. log nature). In reservoir rock, porosity is the main petrophysical parameter that strongly is controlled by facies and diagenetic processes (Ahr, 2008; Esrafili-Dizaji and Rahimpour-Bonab, 2009).The amount of porosity versus each facies of carbonate and clastic part of the formation are shown in figure 3. Sedimentary features and depositional textures are reflected in the effect of porosity on the elastic parameters, therefore these parameters are also affected by porosity (Weger et al., 2009; Fabricius et al., 2010; Fournier et al., 2011; Fournier et al., 2014). Analyzing the cross plot of porosity (in different facies) versus elastic parameters (Young's, Bulk, Shear and Poisson's), it could be concluded that the Young's modulus showsa higher correlation with porosity and facies (figure 4). Among the elastic parameters, Young's modulus has the highest relationship with the texture and particle or grain to cement or mud ratio changes. However, lithology changes specially anhydrite in this study can strongly influence the Poisson's ratio in each texture (Abdlmutalib et al., 2015). Actually, lithology changes can create discrepancy on PR without considerable texture changes. For example, anhydrite can increase the PR independent from texture changes while the goal of this study is rock elastic changes in the framework of facies and depositional texture. The Asmari Formation in the studied field shows a variable lithology from limestone, dolomite, limy dolostone, dolomitic limestone, anhydrite limestone, anhydrite, sandstone to sandy/silty shale. Seemingly, the observed lithological variations and their related diagenesis along with changes in the facies and texture are responsible for discrepancy in the Poisson's ratio. Considering the results of the current study, Young's modulus shows a higher correlation with the porosity and facies and so is selected for RMF investigation.

Formation elastic properties i.e. Young’s modulus are calculated by using equation below (Kowalski, 1975; Castagna, 1985):

$$
\mathrm{E}_{(\mathrm{psi})}=\left(\frac{\rho_{\mathrm{b}}}{\Delta \mathrm{t}_{\mathrm{S}}^{2}}\right)\left(\frac{3 \Delta \mathrm{t}_{\mathrm{S}}^{2}-4 \Delta \mathrm{t}_{\mathrm{P}}^{2}}{\Delta \mathrm{t}_{\mathrm{S}}^{2}-\Delta \mathrm{t}_{\mathrm{P}}^{2}}\right) 1.34 \times 10^{10}
$$


Where $E_{\text {Dyn }}$ is the dynamic Young's modulus (psi), $\rho b$ is rock bulk density $\left(\mathrm{g} / \mathrm{cm}^{3}\right), \Delta \mathrm{t}_{\mathrm{s}}$ is $\mathrm{S}$-wave travel time or shear slowness $(\mu \mathrm{s} / \mathrm{f})$ and $\Delta \mathrm{t}_{\mathrm{P}}$ is P-wave travel time or compressional slowness $(\mu \mathrm{s} / \mathrm{f})$. By this equation, sonic and density logs can continuously evaluate formation elastic properties along the wellbore. The deformation behavior of sedimentary rocks is characterized by elastic modulus as Young's modulus. Water saturation, depositional texture and pore space affect the elastic moduli (Fabricius et al., 2010). Furthermore, the previous studies show that the elastic properties of sedimentary rocks are strongly controlled by pore type architecture that is created by both depositional and diagenetic processes (e.g. Anselmetti and Eberli, 1993; Eberli et al., 2003; Weger et al., 2009, Fournier et al., 2014).

The Young's modulus changes and sedimentological characteristics (facies, texture and pore type) are investigated in three key wells. In each facies, rock mechanical parameters and petrophysical as well as sedimentological properties are determined (figure 5). According to the results, rock mechanical facies are defined in the Asmari reservoir at Cheshmeh-Khosh oilfield. In this study, RMFs are defined on the base of sedimentary environment, facies, texture, pore type, petrophysical properties and Young's modulus. The Asmari Formation in the studied oil field is subdivided into seven RMFs (Table 2) which are described as follows. RMFs 1 to 4 are defined in the carbonate interval but RMFs 5 to 7 are distinguished in the clastic interval.

\section{RMF1}

RMF1 consists of fine-grained microcrystalline limestone and dolomite (dolomudstone) associated with anhydrite patches (figure 6a). Dominant sedimentary texture in this RMF is mudstone, wackestone and rarely cemented coralline boundstone. The predominance of mud-dominated facies indicates low energy environment (Tucker and Wright, 1990) with low water turbulence (Geel, 2000). RMF1 deposited in intertidal, lagoon (D2 and D3) and open marine environments with dominance of microporosity. Thus, the porosity and saturation value is low and Young's modulus is high (Table 2).

\section{RMF2}


RMF2 is deposited in a higher energy environment and its common rock component is skeletal fragments and intraclasts that in some cases recrystallized to dolomite. The particles with poor to medium sorting are fine to medium in size and vary from sub-angular to rounded with packstone to rarely grainstone and coral boundstone texture (figure 6b). Inner ramp deposits represent a wider spectrum of marginal marine deposits, indicative of a medium to high energy. RMF2 is deposited in back-shoal or lagoonal shoal margins, tidal channel, lagoon (D1), open lagoon and shallow open marine. Common pore types include micropore and mesopore interparticle, micropore and mesopore intercrystaline (c.f. Lønøy, 2006), intraparticle and vug. These pore types in some cases are plugged by calcite cement and rarely by anhydrite cement in dolostonefacies. The amount of Young's modulus, porosity and saturation in this RMF is medium (Table 2).

\section{RMF3}

RMF3 consists of medium to thick bedded grainstone and rarely packstone (figure 6c). The ooid grains are well sorted fine- to coarse-sand size. It is interpreted to have been deposited under shallow-water, high-to moderate energy and above the fair weather wave base condition based on grainy texture, ooids, intraclasts, miliolids bioclasts and well-sorted components. Although the interparticle porosity is the main pore type, dolomite with macropore intercrystalline porosity (c.f. Lønøy, 2006) is also present due to sporadic ooids recrystallization to dolomite. Very well sorted ooid grainstone in shoal facies is dominant in RMF3. Wellconnected interparticle pore type led to high properm values. Dominant rock texture in this RMF are grainstone to packstone. The amount of Young's elastic modulus in this RMF is low and porosity and saturation is high (Table 2).

\section{RMF4}

RMF4 is similar to RMF3 but interparticle and intercrystalline pore space is plugged by blocky anhydrite and calcite cements (figure 6d). In some samples ooids completely recrystallized to dolomite (dolograinstone with micro and mesopore porosity). Dissolution and cementation are common diagenetic 
processes that led to creation of oomoldic and vuggy porosities in the shoal and back-shoal facies. Porosity and permeability strongly are reduced due to cementation. Besides, the value of Young's elastic modulus is very high and saturation is very low (Table 2).

\section{RMF5}

RMF5 includes medium to coarse sand and gravels (figure 6e). Such clean sands are lose and not cemented. Moreover, these arenites are well-sorted but not well-rounded. These sedimentological features suggest deposition in a barrier island and incised valley fill. Well-connected intergranular pore type creates porous and permeable facies. The values of Young's elastic modulus in RMF5 is low and saturation is very high (Table 2).

\section{RMF6}

Shalysilty sand with fine intergranular porosity is the main rock fabric in RMF6 (figure 6f). The depositional texture is quartz wacke and sandy mudstone (Pettijohn et al., 1987). Sand grains are not cemented but infiltrated or diagenetic clay filled the pore space between the sand grains. Silty fine sand with thin inter layer shale suggest deposition in three environments including lower shoreface to offshore, upper shoreface and intertidal. Fine sand and muddy matrix reduced the properm value in RMF6. The value of Young's elastic modulus and saturation in this RMF is medium (Table 2).

\section{RMF7}

Cemented sandstone in the siliciclastic interval of the Asmari is associated with very low thickness (figure $6 \mathrm{~g})$. This facies is restricted to the margins of the basin with lithic arenite/wacke texture. Only two cement types (calcite and dolomite) occurred in the sandstones. Stratigraphical position shows sandstones with dolomite cement are in the shoreface and barrier but sandstones with calcite cement commonly occur in the base of channels. Such cements occlude the pore space in the sandstones and reduce the reservoir quality. The magnitude of Young's modulus in this facies is higher than RMF6 and saturation value is very low 
(Table 2). In some facies, Young's modulus show anomalous values especially in carbonate intervals which could be justified by the presence of the fractures that generally reduces the Young's modulus. In figure 5 distribution of seven RMFs and their properties in one of the studied wells are shown.

Generally, the elastic properties of sedimentary rocks show inverse relations with the porosity values (Fabricius et al., 2010). Plot of the Young’s modulus versus porosity in each RMF (figure 4a\&a’) reflects different depositional facies, textures and pore types. Acoustic velocity in sedimentary rocks, especially in carbonates, is dependent on pore type (Anselmetti and Eberli, 1999; Kenter et al., 2002;Eberli et al., 2003; Weger et al., 2009), hence, the pore type affect the elastic moduli (Verwer; 2010). Distribution of RMFs in one of the studied wells is graphically illustrated in figure 5. As illustrated for each RMFs texture, facies, ratio of particle or grain to cement or mud, saturation, pore type, porosity and Young's modulus are determined. This integrated approach for RMFs classification indicates the sedimentological, petrophysical and elastic properties of reservoir rock.

\section{3D model of rock mechanical facies}

Most mechanical parameters, even today, are one-dimensional (1D), based on well and drilling data alone. The concept of using seismically derived horizons and velocities to extend the rock mechanical parameters into 3D space was introduced in recent years. Seismic attributes can estimate the rock-mechanical properties from seismic in a physically meaningful way. An important step in creation of a realistic 3D geomechanical model is definition of mechanical properties as a function of formation and position (Zee et al., 2012). In this study, statistical methods are used for exploration of well information guided by seismic information

to construct 3D volume of the RMF. In addition to the rock mechanical parameters, porosity is also predicted by seismic attributes as it strongly affects the rock elastic properties (Fabricius et al., 2010).

Log-derived RMFs (Dynamic Young's modulus) led to predictive capability for application of RMFs in the field by allowing RMF classes to be determined from log data. Linking the seismic attribute to dynamic 
elastic modulus (calculated from logs) is used for defining the dynamic elastic parameters measured in the field.

Using high-quality seismic data serves as a favorable method for the assessment of rock mechanical parameters (Young's modulus) in the field scale with geophysical approach. Checkshot data, post-stack 3D seismic data and target logs (Young's modulus and porosity) along with the sonic and density logs were available for three wells. Well log data were correlated with seismic data through the construction of synthetic seismograms (figure 7). The seismic synthesis record can be expressed as the convolution of the seismic wavelet and reflection coefficient. The seismic wavelet is obtained through the multi-trace seismic statistical method and the reflection coefficient is obtained mainly through the acoustic log data (the acoustic velocities from the sonic logs are multiplied by the bulk density values from density logs). Depthto-time conversion of the well logs was accomplished by applying checkshot data supplied for wells CK\#5

and CK\#3. It was necessary to create synthetic seismogram and extract the wavelets repeated for the placement of the log data in time. This depth-to-time process allowed for a comparison of the well logs, and their associated tops, with the seismic data in time. After the initial quality control (depth shifting, spike deleting, bad data deleting) of the input data, the well data is correlated with the seismic data and a zero phase wavelet is extracted. The amplitude, phase and frequency spectrum of the final wavelet used for the inversion of seismic data to acoustic impedance is shown in figure 8.

\subsection{D acoustic impedance inversion}

For acoustic impedance inversion, first, an initial model is built from the low frequency component of the well log. The inversion process is applied at each well location and the inversion parameters are determined. The inversion process is then applied to the entire dataset in target window (between top \& base of the Asmari Formation).

Among the several algorithms for inversions, the model-based inversion algorithm is preferred here because of lower error and higher cross validation (Brown, 1996). The model-based inversion method is a 
generalized linear inversion (GLI) algorithm, in which each trace of synthetic seismogram is calculated by the initial predicted impedance and a known wavelet. During the inversion, impedance is progressively modified, until the resulting synthetic trace matches the real trace with acceptable level. The operator controls how far the algorithm may move from the initial guess in order to match the real data. This parameter defines how the algorithm is constrained in moving from the initial guess to the last answer. The mean correlation between synthetic seismogram and composite trace at the well locations of the studying formation is calculated as high as 0.9. Therefore, the model-based inversion method with the GLI algorithm was found effective for the seismic data inversion. The initial inversion model is constructed by interpolating and extrapolating the log data in the 3D seismic volume. Afterwards, a cube of full band acoustic impedance was obtained that serves as the most important attribute for the Young's modulus and porosity estimation (figure 9). The inversion result in target horizon is quality controlled by applying time slices of a window centered (Yematawork et al., 2010).

\subsection{Selection of optimal seismic attributes}

The inverted acoustic impedance data together with other seismic attributes were used for mapping seismic data into rock mechanical parameters and porosity. Uncertainty of the 3D models was reduced when a valid relationship was established between seismic measurements and target logs at well locations. The relationships between input (seismic attributes) and output data (target logs) are investigated through the statistic and intelligent methods. In multi-attribute regression method, among all seismic attributes, the first attribute is chosen based on lowest average error and higher correlation with the target log. The stepwise regression technique is implemented to define the best combination of attributes with the lowest prediction error. The convolution algorithm is adopted to eliminate the difference in the frequency of the log and seismic attributes. Then the single sampling point on the log-seismic attributes is expanded to the adjacent multiple sampling points to correlate with the target log. The weighted average of the sampling points group on each attributes is selected to calculate a point on the predictive log, which has almost the same resolution with target log. Also determination of optimal operator length for any given set of attributes is caused to 
higher correlation between the actual target logs and the predicted target logs. In this study for Young's modulus prediction stepwise regression find the combination of 2 attributes (Acoustic Impedance and Instantaneous Phase) out of the total list of attributes for given operator length 7. Furthermore Porosity is estimated with combination of 8 attributes and with operator length 3 . Table 3 represents the multi-attribute list to formulate seismic data to Young's modulus and porosity. The first attribute that have relation with Young's modulus and porosity is Inversion Result or Acoustic Impedance. Acoustic impedance is a product of sonic velocity and bulk density. There is an inverse relationship between velocity and bulk density. Accordingly, porosity is an inverse function of acoustic impedance. Also, Instantaneous Phase and Integrated Absolute Amplitude among the all attributes are the highest correlation with Young's modulus and Porosity respectively. Instantaneous Phase attribute have close relation with porosity and lithology changes also Young's modulus changes is dependent on porosity and facies variation. Integrated Absolute amplitude is sum of all the trace amplitudes within the window interval. As with the integrate attribute, it can indicate amplitude anomalies as a result of lithology and porosity variations (Chen and Sidney, 1997).

Stepwise regression determined the best attributes to have the closest relation with the target logs but an attempt is made to map seismic attributes into target logs by using a neural network method. Three neural network algorithms including probabilistic (PNN), multilayer feed forward (MLFN) and radial basis function (RBF) were utilized for final estimation of target logs cube from a set of predefined seismic attributes. The probabilistic neural network (PNN) with correlation of 0.9000 and mean error of 819480 psi and correlation 0.8015 and mean error of 0.02553 in the validation set was found to have the best performance to predict respectively for Young's and Porosity (Table 4). The estimated log from seismic attributes was found very comparable to the original log in the well location (Figure 10) due to the nonlinear nature of the neural network and the complex and non-linear relation between seismic attribute and target parameter (Kadkhodaie-Ilkhchi et al., 2009). Results of the propagated Young's modulus and porosity from seismic attributes and intelligent method in both carbonate and clastic parts of the Asmari reservoir are illustrated in figures 11 and 12, respectively. 


\section{Discussion}

In the previous researches, the relation between elastic moduli and porosity, pore type, fluid substitution and saturation were studied (Baechle et al., 2005; Baechle et al., 2009; Verwer et al. 2010;Fabricious 2010). In sedimentary rocks, microstructure is an important factor influencing the elastic moduli (Khazanehdri and Sothcott, 2003). In this paper, our attempt was to create a relationship between facies, texture and elastic modulus. In each facies sedimentological and petrophysical features such as texture, sedimentary environment, pore type, porosity, permeability and cement or mud were considered. Based on these characteristics and elastic modulus rock mechanical facies were defined. The results obtained in this study support the earlier findings so that the changes in elastic modulus are in relation to facies changes. We propose that such changes are in relation to the sedimentary features variations in the studied wells.

In a recent study, facies in carbonate and clastic intervals of the Asmari Formation are described and determined in ten wells of the studied field (Honarmand, 2013). Three wells from the field are selected for determination and correlation of RMFs (figure 13). Twelve facies in carbonate and five facies in clastic intervals of the oil field were determined. In sedimentary rocks, elastic properties and permeability are known to be strongly influenced by the particle or grain to cement or mud ratio (Castagna et al., 1985; Best and katsube, 1995). Also, cementation is the most important diagenetic feature that affected elastic properties. Actually, this ratio reflects the energy level in the depositional environments. By increasing such a ratio, Young’s modulus decreases (softening) and vice versa (stiffening) (figure 5).

In the carbonate part of the Asmari formation within high energy shoal facies ( $\left.\frac{\text { Particle }}{\text { Cement }}>1\right)$ elastic modulus decreases. (RMF3). In some intervals, where shoal facies are cemented by anhydrite and calcite (i.e. $\frac{\text { Particle }}{\text { Cement }}<1$ ), elastic modulus tends to increase (RMF4). In relatively high to medium energy facies such as wackestones and packstones of lagoon margin and shoal where $\frac{\text { Particle }}{\text { Cement }}=1$, the Young's modulus shows a moderate distribution (RMF2). Finally, in low energy facies such as tight dolomudstone and muddy facies within intertidal, restricted lagoon and open marine environments, Young’s modulus shows higher 
values (RMF1). In clastic part of the formation, well-sorted coarse grained sandstone in barrier island and filled incised valley with ratio $\frac{\text { Grain }}{\text { Mud }}>$ 1have higher elastic modulus (RMF5) than the quartz wacke and sandy mudstone with $\frac{\text { Grain }}{\text { Mud }} \geq 1$ (RMF6) in Lower shoreface to offshore and upper shoreface to intertidal environments. In some intervals, in the clastic succession, sandstones cemented by calcite and dolomite with ratio $\frac{\text { Grain }}{\text { Cement }}<1$ that strongly damaged the porosity. Also elastic modulus in this RMF is very high because high cemented sandstone show a stiff behavior (RMF7). According to the results, seven RMFs are recognized in the studied formation for which a very good agreement is available between studied wells (figure 13). This study shows that RMF concept is an applicable method for reservoir characterization and correlation of mechanical properties between wells in the field scale (figure 13).

With the advancement of seismic interpretation and intelligent system, the lateral variation of the formation properties can be characterized with seismic data and geological modeling. A 3D RMF modeling shows lateral variation of RMF over the studied formation. A slice from the Young's modulus distribution with average window of 30 milliseconds below the Asmari horizon in the carbonate interval represents distribution of four RMFs in the carbonate part of the formation (figure 11(A)). Moreover, a slice from the clastic part of the Asmari formation with average window of 40 milliseconds above the Pabdeh horizon represents distribution of three RMFs (figure 11(B)). Since a good agreement is seen between elastic modulus and porosity (an inverse trend) (Baechle et al 2009;Fabricious et al., 2010; Jensen et al., 2011; Fournier et al., 2014), porosity distribution slices from the formation show the same trend of RMFs over the Asmari formation (figure 12 A and B). The Young's modulus and porosity maps show the distribution of RMFs and their related properties in the field scale. Described RMFs in this paper with predictive use of interpreted mechanical stratigraphy is now providing and supplying insights into field development programs. Moreover, the seismic driven 3D geomechanical model can be used for analyzing multiple welltrajectories for optimal well-placement.

\section{Conclusion}


Comparison of facies analysis, sedimentary environments, textures, saturation, pore types, porosity, the ratio of grain to cement or mud and porosity with changes in the ultrasonic Young's elastic modulus yielded the useful information from the Asmari reservoir. Accordingly, seven RMFs are defined in the studied formation. These RMFs are found as an effective tool for correlation of elastic modulus between wells and propagation of the results from wells to the field scale. This paper shows that Young's modulus is strongly controlled and correlated to sedimentary properties of reservoir rocks. In the carbonate intervals of the formation, generally, by increasing energy level in depositional environments from mudstone to grainstone texture (RMF1 to RMF3) Young's modulus increases. Also, in some intervals anhydrite and calcite cements in high energy shoal facies strongly increased the Young's modulus values (RMF4). Moreover, in clastic intervals by decrease in the energy level of depositional environments (i.e. coarse sands to muddy and fine sands) (RMF5 to RMF6) Young's modulus tends to increase. In the clastic part of the formation, coarse sandstones are highly cemented by calcite and dolomite causing strong increase in the Young's modulus (RMF7).

Through defining the RMFs, a better understanding from the distribution of sedimentological, petrophysical and mechanical properties of the formation can be obtained from wells to field scale. Investigation of RMFs mapped by seismic attributes led to propagation of the results and interpretation of anomalies over the reservoir when simulation predictions and well behavior are compared in the field. It is expected that the integrated approach introduced in this study will help in highlighting the stiff and soft zones over the Asmari reservoir rocks.

\section{Acknowledgment}

The authors acknowledge the Iranian Central Oilfields Company (ICOFC) for sponsoring, data preparation and permission for publication of the data. Vice-President of Research and Technology of the University of Tehran is thanked for partial financial support of this study.

\section{Reference}


Abdlmutalib, A., Abdullatif, O., Korvin G., Abdulraheem, A., 2015, The relationship between lithological and geomechanical properties of tight carbonate rocks from Upper Jubaila and Arab-D Member outcrop analog, Central Saudi Arabia. Arab J Geoscience.

Ahr, W.M., 2008. Geology of carbonate reservoirs, John Wiley and Sons, 296 p..

Alsharhan, A.S., Nairn, A.E.M., 1997. Sedimentary Basins and Petroleum Geology of the Middle East. Elsevier, Netherlands.

Anselmetti, F.S., Eberli, G.P., 1993. Controls on sonic velocity in carbonates, Pure and Applied Geophysics141,287-323.

Anselmetti, F.S., Eberli, G.P., 1999. Velocity deviation log: a tool to predict pore type and permeability trends in carbonate drill holes from sonic and porosity or density logs. AAPG Bull. 83, 450-466.

Baechle, G.T., Weger, R.J.,Eberli, G.P., Massafero, J.L., Sun, Y.F., 2005. Changes of shear moduli in carbonate rocks: Implications for Gassmann applicability. The Leading Edge 24, 507-511.

Baechle, G.T., Eberli, G.T., Weger, R.J., Massaferro, J.L., 2009. Changes in dynamic shear moduli of carbonate rocks with fluid substitution. Geophysics 74 (3), 135-147.

Bell, F.G., Culshaw, M.G., Cripps, J.C., 1999. A review of selected engineering geological characteristics of English chalk. Engineering Geology 47, 237-269.

Berberian, M., King, G., 1981. Towards a paleogeography and tectonic evolution of Iran. Canadian J. earth sci. 18(2), 210-265.

Best, M.E., Katsube, T.J., 1995. Shale permeability and its significance on hydrocarbon exploration. The Leading Edge 14 (3), 165-170.

Brahma, J., Sircar, A., 2014. Estimation of the effect of anisotropy on Young's moduli and Poisson's ratios of sedimentary rocks using core samples in western and central part of Tripura. India International Journal of Geoscience5, 184-195.

Brandano, M., Corda, L., 2002. Nutrients, sea level and tectonics: constrains for the facies architecture of a Miocene carbonate ramp in central Italy. Terra Nova 14, 257-262.

Brigaud, B., Vincent, B., Durlet, C., Deconinck, J.-F., Blanc, P., Trouiller, A., 2010. Acousticproperties of ancient shallow-marine carbonates: Effects of depositional environment and diagenetic processes (Middle Jurassic, Paris Basin , France). Journal of Sedimentary Research 80, 791-807.

Brown, A.R., 1996. Seismic attribute and their classification. The Leading Edge, 15, 1090.

Buxton, M.W.N., Pedley, M., 1989. Short paper: a standardized model for Tethyan Tertiary carbonate ramps. Journal of the Geological Society, London 146, 746-748.

Castagna, J.P., Batzle, M.L., Eastwood, R.L., 1985. Relation between compressional-wave and shear-wave velocities in clastic silicate rocks. Geophysics 50 (4), 571-581. 
Chatterjee, R., Mukhopadhyay, M., 2001. Petrophysical and geomechanical properties of rocks from the oilfields of the Krishna-Godavari and Cauvery basins, India. Bulletin of Engineering Geology and Environment 61, 169-178.

Chen, Q., Sidney, S., 1997. Seismic attribute technology for reservoir forecasting and monitoring. The Leading Edge 16 (5), 445-456.

Corda, L., Brandano, M., 2003. Aphotic zone carbonate production on a Miocene ramp Central Apennines, Italy. Sedimentary Geology 61, 55-70.

Dehghani, M.H., Shadizadeh, S.R.,Roozbehani, B., 2014.Geomechanical Modeling Using Well Logs: A Case Study of an Iranian Heterogeneous Carbonate Reservoir. Energy Sources, part A 36, 1555-1570.

Dunham, R.J., 1962. Classification of carbonate rocks according to depositional texture. AAPG Mem. 1, $108-121$.

Dunnington, H.V., 1958. Generation, migration, accumulation and dissipation of oil in northern Iraq. In: Weeks, L.G. (Ed.), AAPG Bull. Habitat of Oil, 1194-1251.

Dunnington, H.V., 1967. Stratigraphic distribution of oilfields in the Iraq-Iran- Arabia Basin. Journal of the Institute of Petroleum 53, 129-161.

Eberli, G.P., Baechle, G.T., Anselmetti, F.S.,Incze, M.L., 2003. Factors controlling elastic properties in carbonate sediments and rocks. The Leading Edge 22, 654-660.

Esrafili-Dizaji, B.,Rahimpour-Bonab, H., 2009. Effects of depositional and diagenetic characteristics on carbonate reservoir quality: a case study from the South Pars gas field in the Persian Gulf. Petroleum Geoscience 15, 325-344.

Fabricius, I.L., Bachle, G.T.,Eberli, G.P., 2010. Elastic moduli of dry and water-saturated - effect of depositional texture porosity and permeability. Geophysics 75(3), 65-78.

Flugel, E., 1982.Microfacies analysis oflimestones. Springer, Berlin, 633 p..

Flugel, E., 2010.Microfacies of carbonate rocks: analysis, interpretation and application. 2nd edn., Springer, Berlin, 984 p..

Fournier, F., Leonide, P., Biscarrat, K., Gallois, A., Borgomano, J., Foubert, A., 2011. Elasticproperties of microporous cemented grainstones. Geophysics 76, 211-226.

Fournier, F., Léonide, P., Kleipool, K., Toullec, R., Reijmer, J.G., Borgomano, J., Klootwijk, T., Van Der Molen, J., 2014. Pore space evolution and elastic properties of platform carbonates (Urgonian limestone, arremian-Aptian, SE France). Sedimentary geology 308, 1-17.

Geel, T., 2000. Recognition of Stratigraphic sequence in carbonate platform and slope deposits: empirical models based on microfacies analyses of palaeogene deposits in southeastern Spain. Palaeogeogr Palaeoclimatol Palaeoecol 155, 211-238.

Ghazvinian, A., Nejati, H.R., Saemi, M., 2012. Reliability and uncertainty of prediction of dynamic elastic constants in reservoir rock SPE paper no. 155503. 
Haynes, S.J., McQuillan, H., 1974. Evolution of the Zagros suture zone, southern Iran. Geological Society of America Bulletin 85, 739-744.

Henson, F.R.S., 1951. Observations on the geology and petroleum occurrences of the Middle East. Proc. 3rd World Petroleum Congress, 1, 118-140.

Honarmand, J., 2013.Sedimentological and diagenetic controls on reservoir properties of the Asmari formation, Cheshmeh-Khosh field, northern part of Dezful Embayment, SW Iran. Ph.D. thesis University of Tehran Tehran 308 p..

Hussain, M., El Hassan, W.M.,Abdulraheem, A., 2006. Controls of grain-size distribution on geomechanical properties of reservoir rock-A case study: Cretaceous Khafji Member, Zuluf Field, offshore Arabian Gulf. Marine and Petroleum Geology 23, 703-713.

James, G.A.,Wynd, J.G., 1965. Stratigraphical nomenclature of Iranian Consortium Agreement Area. AAPG Bull.49, 2182-2245.

Jeng, F.S., Weng, M.C., Lin, M.L., Huang, T.H., 2004. Influence of petrographic parameters on geotechnical properties of Tertiary sandstones from Taiwan. Engineering Geology 73, 71-91.

Jensen, E.H., Andersen, C.F., Johansen, T.A., 2011. Estimation of elastic moduli of mixed porous composites Geophysics 76 (1), 9-20.

Kadkhodaie-Ilkhchi, Rezaee, M.R.,Rahimpour-Bonab, H., Chehrazi, A., 2009. Petrophysical data prediction from seismic attributes using committee fuzzy inference system.Computer and Geoscience35, 2314-2330.

Kenter, J.A.M., Anselmetti, F.S., Kramer, P.H., Westphal, H., Vandamme, M.G.M., 2002. Acoustic properties of "young” carbonate rocks, ODP Leg 166 and boreholes Clino and Unda, Western Great Bahama Bank. Journal of Sedimentary Research 72, 129-137.

Khazanehdari, J.,Sothcott, J., 2003. Variation in dynamic elastic shear modulus of sandstone upon fluid saturation and substitution, Geophysics 68, 472-481.

Kowalski, J., 1975. Formation Strength Parameters from Well Logs. SPWLA 16th Ann. Logging Symp., Society of Petrophysicists and Well-Log Analysts.

Lønøy, A., 2006. Making sense of carbonate pore systems, AAPG Bull. 90, 1381-405.

Motiei, H., 1993. Geology of Iran, the Stratigraphy of Zagros. (Tehran, Geological Survey of Iran), 572 p. (in Persian).

Pettijohn, F.J., Potter, P.E., Siever, R., 1987. Sand and Sandstone, Springer-Verlag, 553 p..

Shakoor, A., Brown, C.L., 1996. Development of a quantitative relationship between unconfined compressive strength and Los Angeles abrasion loss for carbonate rocks. Bulletin of InternationalAssociation of Engineering Geology 53, 97-103. 
Sharland, P.R., Archer, R., Casey, D.M., 2001. Arabian Plate sequence stratigraphy. GeoArabia Special Publication, 2.

Topal, T., Doyuran, V., 1997. Engineering geological properties and durability assessment of the Cappadocian tuff. Engineering Geology 47, 175-187.

Tucker, M. E., Wright, V.P., 1990. Carbonate Sedimentology, Blackwell, Oxford, 482 p.

Van Buchem, F.S.P., Allen, T.,Lausen, G.V.,Lotfpour, M.,Moallemi, A.,Monibi, S.,Motiei, H., Pickard, N.,Tahmasbi, A.R.,Vedrenne, V., Vincent, B., 2010. Sequence stratigraphy and Sr isotope stratigraphy of the Oligo-Miocene deposits in the Dezful Embayment (Asmari and Pabdeh Formations, SW Iran)implications for reservoir characterization.1st International Petroleum Conference European Association of Geoscientists and Engineers (EAGE) 4-6 May Shiraz Iran.

Verwer, K., Braaksma, H., Kenter, J.A.M., 2008. Acoustic properties of carbonates: Effects of rock texture and implications for fluid substitution. Geophysics 73, B51-B65.

Verwer, K., Eberli, G., Baechle, G.,Weger, R., 2010. Effect of carbonate pore structure on dynamic shear moduli. Geophysics 75(1), 1-8.

Weger, R.J., Eberli, G.P., Baechle, G.T., Massaferro, J.L., Sun, Y.F., 2009. Quantification of pore structure and its effect on sonic velocity and permeability in carbonates. AAPG Bulletin 93, 1297-1317.

Wennberg, O.P., Svånå, T., Azizzadeh, M., Aqrawi, A.M.M., Brockbank, P., Lyslo, K.B., Ogilvie, S., 2006. Fracture intensity vs. mechanical stratigraphy in platform top carbonates: the Aquitanian of the Asmari Formation, Khaviz Anticline, Zagros, SW Iran.Petroleum Geoscience 12(3), 235 - 246.

Williams, M.P., Edwards, H.E.,Bratli, R.K., 2012. Rock mechanical facies; classification and use in carbonate reservoirs, Offshore Abu Dhabi. SPE paper no. 161524.

Wilson, J.L., 1975. Carbonate facies in geologic history. Springer, New York, 471 p..

Yematawork, A., Raven, B., Estoque, M., Norgard, J., 2010. Seismic Inversion-A Work Flow For ModelBased Inversion. GeoCanada-Working with the Earth, Calgary.

Zee, W., Hughes, B., Taylor, J.,Brudy, M., 2012. Improving sub salt wellbore srability predictions using 3D geomechanical simulations. SPE paper no. 162313.

Zhang, J., Bently, L.R., 2003.Crewes research report. Vol 15 Calgary Canada: university of Canada. In Rehman, F.,Rehman, S.,Ullah, M.F., Kashif, M., Ahsan, N., Abbas, M., 2014. Conjecturing gross lithologic information using elastic moduli obsessed by rock physics as tool. A case study for khewrasandstone, Fortabbas Area, Pakistan. Energy Sources, Part A 36, 1786-1792. 


\section{Table captions}

Table 1. Microfacies description and facies associations (facies belts) of the Asmari carbonate intervals in the studied wells.

Table 2. Comparative descriptive data of the seven RMFs in the studied formation. In each RMF mean of parameters and brief facies/texture descriptions are shown.

Table 3. Multi attribute table showing combination of ten attributes for estimation of Young's modulus and porosity. As shown after adding first two attributes for Young's modulus and eight attributes for porosity to the prediction list, training error decreases while validation error starts to increase.

Table 4. Probabilistic neural network with highest correlation and lowest error in training and validation set to predict target logs (upper: Young’s modulus, lower: Porosity) from seismic attributes.

\section{Figure captions}

Figure 1. A location map of studied oilfield in the NW of Dezful Embayment and distribution of Asmari Reservoir in the south of Iran.

Figure 2. Conceptual depositional model for carbonate (upper) and clastic (lower) intervals of the Asmari Formation in the studied oilfield. The location of the microfacies determined the main energy surfaces (fair weather wave base and storm wave base) and microfacies illustrations for the main facies belts are shown (modified from Honarmand 2013).

Figure 3. Plot showing range of porosity values within facies of Asmari Formation.

Figure 4. Correlation between dynamic elastic parameters and porosity in different carbonate (A to E) and clastic (F to J) facies. Young’s modulus shows a higher correlation with porosity.

Figure 5. Distribution of seven RMFs in one of the studied wells. In each RMF ratio of grain to mud or cement (energy level of sedimentary environment), pore types and saturation are determined.

Figure 6. Photomicrographs of RMFs (RMF1 to RMF7) from the Asmari Formation in the studied oil fields. a) Mudstone: RMF1; b) Wackestone: RMF2; c) Grainstone: RMF3; d) Cemented and dissolved grainstone: 
RMF 4; e) Coarse and clean sandatone: RMF5; f) Fine and dirty sandstone: RMF6; g) Cemented sandstone: RMF7.

Figure 7. A window of well to seismic tie in well CK\#5 by synthetic seismogram.

Figure 8. Amplitude (left), frequency and phase (right) spectra of the final wavelet used for inversion of seismic data to acoustic impedance.

Figure 9. Inverted acoustic impedance section in the Asmari Formation of Cheshmeh-Khoshoilfield.

Figure 10. Statistically and graphically good correlation and low average error between estimated target logs (red color) and original logs (black color) from probabilistic neural network method are shown for two target logs (right: porosity; left: Young’s modulus).

Figure 11. A) A slice of Young's modulus with average window of 30 millisecond below the Asmari horizon. This map shows the distribution of 4 RMFs in carbonate part of the formation. B) A slice of Young's modulus with average window of 40 millisecond above the Pabdeh horizon. This map shows the distribution of 3 RMFs in clastic part of the formation.

Figure 12. A Slice of porosity with average window of 30 millisecond below the Asmari horizon (A) and 40 millisecond above the Pabdeh horizon (B). These maps indicates inverse relation of Young's modulus and porosity

Figure 13. Main panel shows good correlation of rock mechanical facies (RMFs) identified using texture, facies, $\frac{P \text { or } G}{C \text { or } M}$ ration and amount of Young's modulus between wells CK\#3, CK\#1 and CK\#2 of CheshmehKhosh oilfield. 
Table 1

\begin{tabular}{|c|c|c|c|c|c|c|}
\hline \multirow{2}{*}{$\begin{array}{l}\text { MF } \\
\text { Code }\end{array}$} & \multirow{2}{*}{$\begin{array}{l}\text { Microfacies } \\
\text { name }\end{array}$} & \multirow{2}{*}{$\begin{array}{l}\text { Lithology, } \\
\text { color and } \\
\text { texture }\end{array}$} & \multirow{2}{*}{$\begin{array}{l}\text { Grain size } \\
\text { and sorting }\end{array}$} & Components & \multirow{2}{*}{$\begin{array}{c}\text { Facies } \\
\text { association }\end{array}$} & \multirow{2}{*}{$\begin{array}{l}\text { Interpretation } \\
\text { (environment) }\end{array}$} \\
\hline & & & & Skeletal Non-skeletal & & \\
\hline$M F A$ & $\begin{array}{c}\text { Mudstone, } \\
\text { bioclasticwackeston } \\
\text { e with planktonic } \\
\text { foraminifera }\end{array}$ & $\begin{array}{c}\text { Clayey- } \\
\text { limestone, gray } \\
\text { to black, } \\
\text { mudstone to } \\
\text { wackestone }\end{array}$ & $\begin{array}{l}\text { Calcilutite, } \\
\text { poorly } \\
\text { sorted }\end{array}$ & $\begin{array}{l}\text { Globigerina,lenticulina, } \\
\text { Amphistegina }\end{array}$ & $\begin{array}{l}M F B 1, \\
M F B 2\end{array}$ & $\begin{array}{l}\text { Deep open } \\
\text { marine }\end{array}$ \\
\hline MF B1 & $\begin{array}{l}\text { Bioclasticpacks } \\
\text { tone with large } \\
\text { benthic } \\
\text { foraminifera }\end{array}$ & $\begin{array}{l}\text { Lime, light } \\
\text { brown, } \\
\text { wackestone } \\
\text { /packstone }\end{array}$ & $\begin{array}{l}\text { Calcarenit } \\
\text { e-calcilutite, } \\
\text { poorly/moderat } \\
\text { ely } \\
\text { sorted }\end{array}$ & $\begin{array}{c}\text { Lepidocyclina, } \\
\text { Asterigerina, Amphistegina, } \\
\text { Heterostegina, Operculina, } \\
\text { Ostrea,Operculina }\end{array}$ & $\begin{array}{l}M F A, M F \\
\quad B 2\end{array}$ & $\begin{array}{l}\text { Shallow open } \\
\text { marine }\end{array}$ \\
\hline$M F B 2$ & $\begin{array}{l}\text { Bioclastic, red } \\
\text { algae, echinoderm, } \\
\text { rotaliapackstone }\end{array}$ & $\begin{array}{l}\text { Lime, gray } \\
\text { to cream, } \\
\text { Packstone }\end{array}$ & $\begin{array}{l}\text { Calcarenit } \\
\text { e-calcilutite, } \\
\text { moderately } \\
\text { sorted }\end{array}$ & $\begin{array}{c}\text { Lithothamnium, } \\
\text { Lithophyllum, } \\
\text { Asterigerinarotula ‘Operculina } \\
\text { complanata ‘Amphistegina } \\
\text { lesson, Lepidocyclina }\end{array}$ & $\begin{array}{l}M F A, M F \\
B 2, M F C 1\end{array}$ & $\begin{array}{l}\text { Shallow open } \\
\text { marine }\end{array}$ \\
\hline$M F C 1$ & Ooidgrainstone & $\begin{array}{c}\text { Lime, } \\
\text { dolomite, light } \\
\text { yellow, } \\
\text { grainstone }\end{array}$ & $\begin{array}{l}\text { Calcarenit } \\
\text { e, calcirudite, } \\
\text { well sorted }\end{array}$ & (1) & $\begin{array}{c}M F C 2, \\
M F \text { C3, MF B2, }\end{array}$ & Barrier, shoal \\
\hline$M F C 2$ & $\begin{array}{c}\text { Bioclastic, } \\
\text { faverina, } \\
\text { ooidgrainstone }\end{array}$ & $\begin{array}{c}\text { Lime, } \\
\text { brown, } \\
\text { grainstone }\end{array}$ & $\begin{array}{l}\text { Calcarenit } \\
e, \text { well sorted }\end{array}$ & $\begin{array}{l}\text { Dendritina‘Milliolid, } \\
\text { Gastropoda, } \\
\text { Faverinaasmaricus, } \\
\text { Foraminifera }\end{array}$ & $\begin{array}{l}\text { MF C1 and } \\
C 2, M F D 1 \text { and } \\
D 2\end{array}$ & Barrier, shoal \\
\hline MF C3 & $\begin{array}{c}\text { Miliolid, } \\
\text { dendritinagrainston } \\
e\end{array}$ & $\begin{array}{c}\text { Lime, } \\
\text { dolomite, cream } \\
\text { to blacky gray, } \\
\text { grainstone, } \\
\text { Packstone }\end{array}$ & $\begin{array}{l}\text { Calcarenit } \\
e \text {, well sorted }\end{array}$ & $\begin{array}{c}\text { Fossil fragments, } \\
\text { Peneroplisevolutus, } \\
\text { foraminifera, } \\
\text { Dendritina ‘Milliolid, Ooid, } \\
\text { Peloids }\end{array}$ & $\begin{array}{c}M F C 2, \\
M F D 1 \text { and } D 2\end{array}$ & Barrier, shoal \\
\hline$M F D 1$ & $\begin{array}{l}\text { Miliolidbioclast } \\
\text { packstone }\end{array}$ & $\begin{array}{c}\text { Lime, } \\
\text { dolomite, light } \\
\text { gray to light } \\
\text { brown, } \\
\text { grainstone }\end{array}$ & $\begin{array}{c}\text { Calcarenit } \\
\text { e-calcilutite, } \\
\text { poorly/moderat } \\
\text { ely sorted }\end{array}$ & $\begin{array}{c}\text { Echinoderms, Red } \\
\text { algae, Bivalves, } \\
\text { Dendritina } \text { Milliolid, } \\
\text { Gastropoda }\end{array}$ & $\begin{array}{l}\text { MF D2 and } \\
D 3, M F C 3\end{array}$ & Lagoon \\
\hline MF D2 & $\begin{array}{c}\text { Miliolid, } \\
\text { denderitinawackest } \\
\text { one-packstone }\end{array}$ & $\begin{array}{l}\text { Lime, } \\
\text { dolomite, gray } \\
\text { to light brown, } \\
\text { wackestone- } \\
\text { packstone }\end{array}$ & $\begin{array}{l}\text { Calcarenit } \\
\text { e-calcilutite, } \\
\text { moderately } \\
\text { sorted }\end{array}$ & $\begin{array}{c}\text { Foraminifera, } \\
\text { ‘Dendritina ‘Milliolid, } \\
\text { Gastropoda, Bivalve } \\
\text { fragments, } \\
\text { Borelis,Peneroplis, Peloids, } \\
\text { Charophyta }\end{array}$ & $\begin{array}{c}M F D 3, \\
M F D 1, M F C 3\end{array}$ & Lagoon \\
\hline MF D3 & $\begin{array}{r}\text { Coral } \\
\text { boundstone }\end{array}$ & $\begin{array}{l}\text { Lime, } \\
\text { cream, brown, } \\
\text { boundstone }\end{array}$ & $\begin{array}{l}\text { Calcarenit } \\
\text { e-calcilutite, } \\
\text { moderately } \\
\text { sorted }\end{array}$ & Coral & $\begin{array}{c}M F E 1, \\
M F D 2 \text { and D1 }\end{array}$ & Lagoon \\
\hline MF E1 & $\begin{array}{l}\text { Non-laminated } \\
\text { fine-grained } \\
\text { dolomitized } \\
\text { mudstone }\end{array}$ & $\begin{array}{l}\text { Dolomite, } \\
\text { anhydrite, lime, } \\
\text { cream to brown, } \\
\text { mudstone }\end{array}$ & $\begin{array}{l}\text { Calcilutite, } \\
\text { well sorted }\end{array}$ & Anhydrite nodules & $\begin{array}{c}\text { MF D3, } \\
\text { MF E2 and E3 }\end{array}$ & Intertidal \\
\hline MF E2 & $\begin{array}{l}\text { Laminated fine- } \\
\text { grained dolomitized } \\
\text { mudstone with } \\
\text { evaporate } \\
\text { interlayers }\end{array}$ & $\begin{array}{l}\text { Dolomite, } \\
\text { anhydrite, lime, } \\
\text { cream to brown, } \\
\text { mudstone }\end{array}$ & $\begin{array}{l}\text { Calcilutite, } \\
\text { well sorted }\end{array}$ & Anhydrite nodules & $\begin{array}{l}\text { MF E1 and } \\
\quad \text { E3 }\end{array}$ & Intertidal \\
\hline MF E3 & $\begin{array}{l}\text { Peyssonneliace } \\
\text { apackstone }\end{array}$ & $\begin{array}{l}\text { Lime, } \\
\text { dolomite }\end{array}$ & $\begin{array}{l}\text { Calcarenit } \\
\text { e-calcilutite, } \\
\text { moderatly } \\
\text { sorted }\end{array}$ & Stromatolite & $\begin{array}{l}\text { MF E2 and } \\
\quad \text { E1 }\end{array}$ & Intertidal \\
\hline
\end{tabular}




\begin{tabular}{|c|c|c|c|c|c|c|c|c|}
\hline $\begin{array}{l}R M F \\
s\end{array}$ & $\begin{array}{l}\text { Avg. } \\
E \\
x 10^{6} \\
(p s i)\end{array}$ & $\begin{array}{l}\text { Avg. } \\
\Phi(\%)\end{array}$ & $\begin{array}{l}\text { Avg. } \\
K \\
(m D)\end{array}$ & $\frac{P \text { or } G}{C \text { or } M}$ & $\begin{array}{l}\text { Energy } \\
\text { level }\end{array}$ & Saturation & $\begin{array}{l}\text { Pore } \\
\text { Type }\end{array}$ & Texture and Facies \\
\hline 1 & 10 & 7 & 1 & $<1$ & Low & Low & Microporosity & $\begin{array}{c}\text { Mudstone/Dolomudstone } \\
(E 1, E 3) \text { and Wackestone (D2), } \\
\text { Intertida (E), Lagoon (D2, D3) and } \\
\text { Deep Marine (A) }\end{array}$ \\
\hline 2 & 8 & 15 & 50 & 1 & Medium & Medium & $\begin{array}{c}\text { Fine } \\
\text { Interparticle\&Inter } \\
\text { crystalline, Moldic, } \\
\text { Vug }\end{array}$ & $\begin{array}{l}\text { Wackestone and Packstone (C- } \\
\text { D), Back-Shoal or Lagoonal Shoal } \\
\text { Margin, Tidal Channel, Lagoon } \\
\text { (D1), Open Lagoon and Shallow } \\
\text { Open Marine (B) }\end{array}$ \\
\hline 3 & 4 & 20 & 350 & $>1$ & High & High & $\begin{array}{l}\text { Coarse Interparticle } \\
\text { and Intercrystalline }\end{array}$ & $\begin{array}{l}\text { Ooids (C1), Intraclasts, and } \\
\text { BioclastsGrainstone (C2), Shoal } \\
\text { (C), Shallow Open Marine (B2) }\end{array}$ \\
\hline 4 & 11.5 & 3 & 0.1 & $<1$ & High & Very Low & $\begin{array}{l}\text { Microporosity, } \\
\text { Moldic and Vug }\end{array}$ & $\begin{array}{c}\text { Packstone to Dolomitized } \\
\text { Grainstone (C3,D1), Back Shoal and } \\
\text { Shoal (C) }\end{array}$ \\
\hline 5 & 4 & 22 & 1200 & $>1$ & High & Very High & $\begin{array}{c}\text { Coarse } \\
\text { Intergranular }\end{array}$ & $\begin{array}{l}\text { Arenite, Barrier Island (I) and } \\
\text { Incised Valley Filled }(G)\end{array}$ \\
\hline 6 & 5 & 12 & 150 & 1 & $\begin{array}{l}\text { Medium } \\
\text { to Low }\end{array}$ & Medium & Fine Intergranular & $\begin{array}{c}\text { Quartz Wacke and Sandy } \\
\text { Mudstone (J), Lower Shoreface to } \\
\text { Offshore (F), Upper Shoreface and } \\
\text { Intertidal }(H)\end{array}$ \\
\hline 7 & 8.5 & 5 & 0.5 & $<1$ & Medium & Very Low & Microporosity & $\begin{array}{l}\text { Lithic arenite/wacke, Shoreface } \\
(H), \text { Barrier Island (I)and Channel } \\
\text { fill sediments }(G-H)\end{array}$ \\
\hline
\end{tabular}

Table 2 


\begin{tabular}{|c|c|c|c|c|c|c|}
\hline \multirow{2}{*}{ No. } & \multirow{2}{*}{ Target } & \multirow{2}{*}{ Final Attribute } & \multicolumn{2}{|c|}{ Training } & \multicolumn{2}{|c|}{ Validation } \\
\hline & & & Correlation & Error & Correlation & Error \\
\hline 1 & $\begin{array}{l}\text { Sqrt(Young's } \\
\text { Modulus) }\end{array}$ & (Inversion Result) $^{* * 2}$ & 0.9264 & 801390.3299 & 0.8378 & 870413.2044 \\
\hline 2 & $\begin{array}{c}\text { Sqrt(Young's } \\
\text { Modulus) }\end{array}$ & Instantaneous Phase & 0.9137 & 738414.4071 & 0.8791 & 867266.1076 \\
\hline 3 & $\begin{array}{c}\text { Sqrt(Young's } \\
\text { Modulus) }\end{array}$ & Instantaneous Frequency & 0.9619 & 649507.5951 & 0.8167 & 1492949.6887 \\
\hline 4 & $\begin{array}{c}\text { Sqrt(Young's } \\
\text { Modulus) }\end{array}$ & Integrated Absolute Amplitude & 0.9689 & 609365.8821 & 0.6276 & 1643057.9806 \\
\hline 5 & $\begin{array}{c}\text { Sqrt(Young's } \\
\text { Modulus) }\end{array}$ & Dominant Frequency & 0.9774 & 577390.0753 & 0.3159 & 6036391.5273 \\
\hline 6 & $\begin{array}{c}\text { Sqrt(Young's } \\
\text { Modulus) }\end{array}$ & Average Frequency & 0.9834 & 541330.4981 & 0.1293 & 3241220.5542 \\
\hline 7 & $\begin{array}{c}\text { Sqrt(Young's } \\
\text { Modulus) }\end{array}$ & Apparent Polarity & 0.9854 & 514184.8522 & 0.3589 & 3249612.4392 \\
\hline 8 & $\begin{array}{c}\text { Sqrt(Young's } \\
\text { Modulus) }\end{array}$ & $\begin{array}{c}\text { Second Derivative } \\
\text { Instantaneous Amplitude }\end{array}$ & 0.9877 & 482283.9835 & 0.3781 & 3578807.1620 \\
\hline 9 & $\begin{array}{c}\text { Sqrt(Young's } \\
\text { Modulus) }\end{array}$ & Integrate & 0.9911 & 450526.2589 & 0.4901 & 24653830.5388 \\
\hline 10 & $\begin{array}{c}\text { Sqrt(Young's } \\
\text { Modulus) }\end{array}$ & Amplitude Weighted Phase & 0.9946 & 435227.1189 & 0.4696 & 25780861.7820 \\
\hline
\end{tabular}

Table 3a 


\begin{tabular}{|c|c|c|c|c|c|c|}
\hline \multirow{2}{*}{ No. } & \multirow{2}{*}{ Target } & \multirow{2}{*}{ Final Attribute } & \multicolumn{2}{|c|}{ Training } & \multicolumn{2}{|c|}{ Validation } \\
\hline & & & Correlation & Error & Correlation & Error \\
\hline 1 & $\begin{array}{c}\text { Porosity } \\
\text { Log }\end{array}$ & (Inversion Result) $^{* * 2}$ & 0.9512 & 0.0287 & 34.21 & 0.0304 \\
\hline 2 & $\begin{array}{c}\text { Porosity } \\
\text { Log }\end{array}$ & $\begin{array}{c}\text { Derivate Instantaneous } \\
\text { Amplitude }\end{array}$ & 0.7903 & 0.0274 & 0.4911 & 0.0291 \\
\hline 3 & $\begin{array}{c}\text { Porosity } \\
\text { Log }\end{array}$ & Cosine Instantaneous Phase & 0.8675 & 0.0259 & 0.1930 & 0.0302 \\
\hline 4 & $\begin{array}{c}\text { Porosity } \\
\text { Log }\end{array}$ & Amplitude Weighted Phase & 0.9854 & 0.0254 & 0.4321 & 0.0293 \\
\hline 5 & $\begin{array}{c}\text { Porosity } \\
\text { Log }\end{array}$ & Instantaneous Phase & 0.9243 & 0.0253 & 0.6534 & 0.0298 \\
\hline 6 & $\begin{array}{c}\text { Porosity } \\
\text { Log }\end{array}$ & Average Frequency & 0.9981 & 0.0252 & 0.7943 & 0.0295 \\
\hline 7 & $\begin{array}{c}\text { Porosity } \\
\text { Log }\end{array}$ & Apparent Polarity & 0.9389 & 0.0251 & 0.5678 & 0.0291 \\
\hline 8 & $\begin{array}{c}\text { Porosity } \\
\text { Log }\end{array}$ & Integrated Absolute Amplitude & 0.8028 & 0.0249 & 0.8293 & 0.0290 \\
\hline 9 & $\begin{array}{c}\text { Porosity } \\
\text { Log }\end{array}$ & Dominant Frequency & 0.9566 & 0.0246 & 0.6567 & 0.0292 \\
\hline 10 & $\begin{array}{c}\text { Porosity } \\
\text { Log }\end{array}$ & Derivative & 0.9771 & 0.0244 & 0.2765 & 0.0299 \\
\hline
\end{tabular}

Table 3b 
Table 4b

\begin{tabular}{|l|l|c|c|c|c|}
\hline \multirow{2}{*}{ Network } & \multicolumn{2}{|c|}{ Final Attribute } & \multicolumn{2}{c|}{ Training } & \multicolumn{2}{c|}{ Validation } \\
\cline { 3 - 6 } & & Correlation & Error & Correlation & Error \\
\cline { 2 - 5 } & Integrated Absolute Amplitude & 0.9552 & 0.0125 & 0.8015 & 0.0253 \\
\hline \multirow{3}{*}{ PNN } & Number of layer & Number of neurons in the hidden layer & & \\
\cline { 2 - 5 } & \multicolumn{2}{|l|}{ Maximum epochs in PNN } & & \\
\hline
\end{tabular}

Table 4a

\begin{tabular}{|l|l|c|c|c|c|}
\hline \multirow{4}{*}{ Network } & \multicolumn{2}{|c|}{ Final Attribute } & \multicolumn{2}{c|}{ Training } & \multicolumn{2}{c|}{ Validation } \\
\cline { 3 - 6 } & \multicolumn{1}{|c|}{ Correlation } & Error & Correlation & Error \\
\cline { 3 - 5 } & Instantaneous Phase & 0.9325 & 729989 & 0.9000 & 819480 \\
\hline \multirow{3}{*}{ PNN } & Number of layer & & & 5 \\
\cline { 2 - 5 } & Number of neurons in the hidden layer & & 11 \\
\cline { 2 - 5 } & Maximum epochs in ANN & & \\
\hline
\end{tabular}




\section{Research highlights}

- Studying the connection between facies distribution and elastic modulus

- Introduction of Rock Mechanical Facies(RMF) concept

- Relation between grain to matrix ratio with Young's modulus

- Construction of 3D model RMFs

- Correlation of RMFs concept among the wells. 


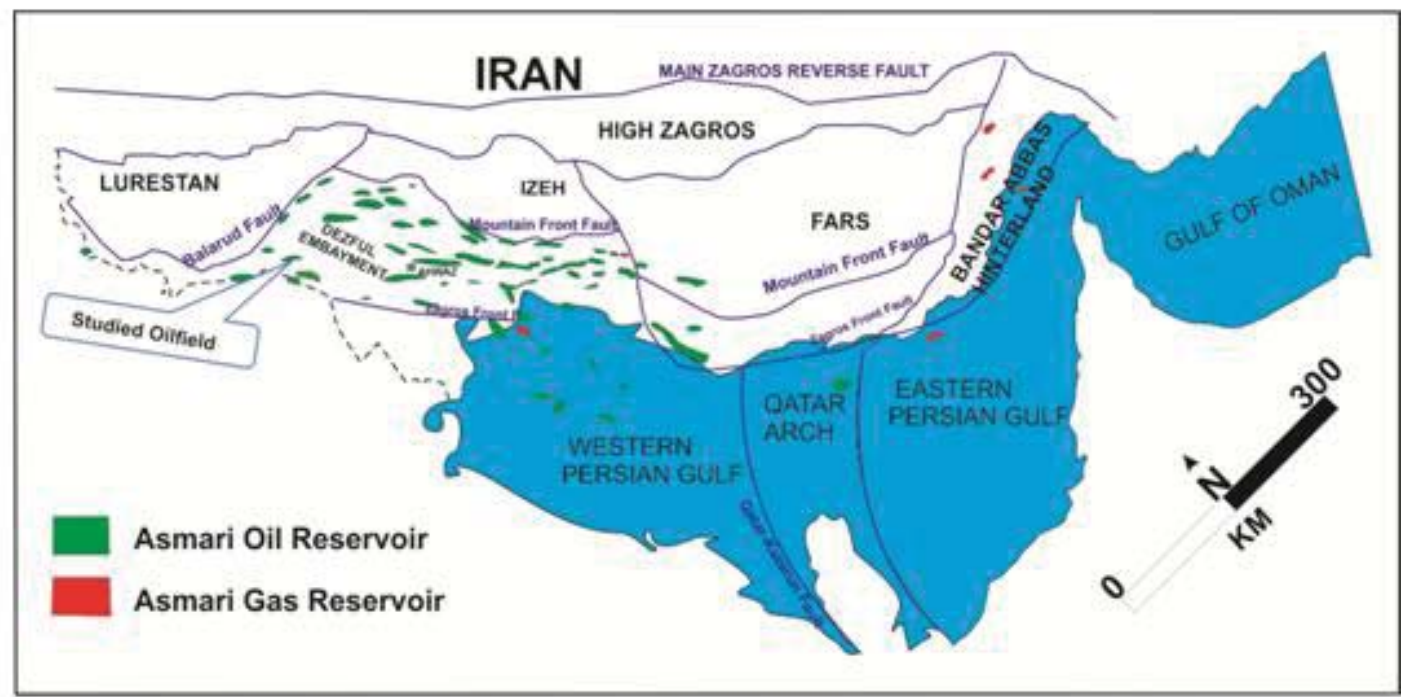

Figure 1 


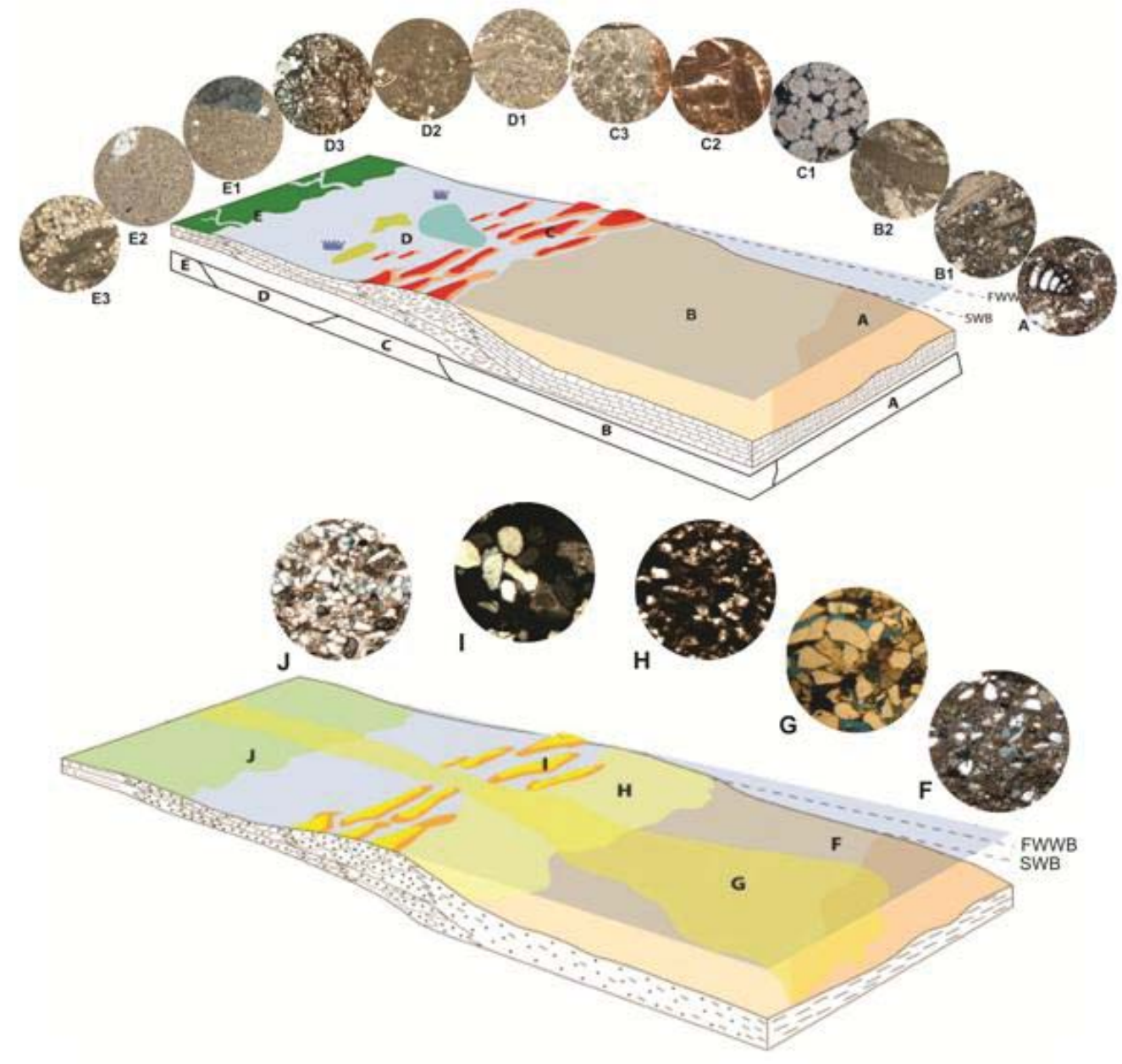

Figure 2 

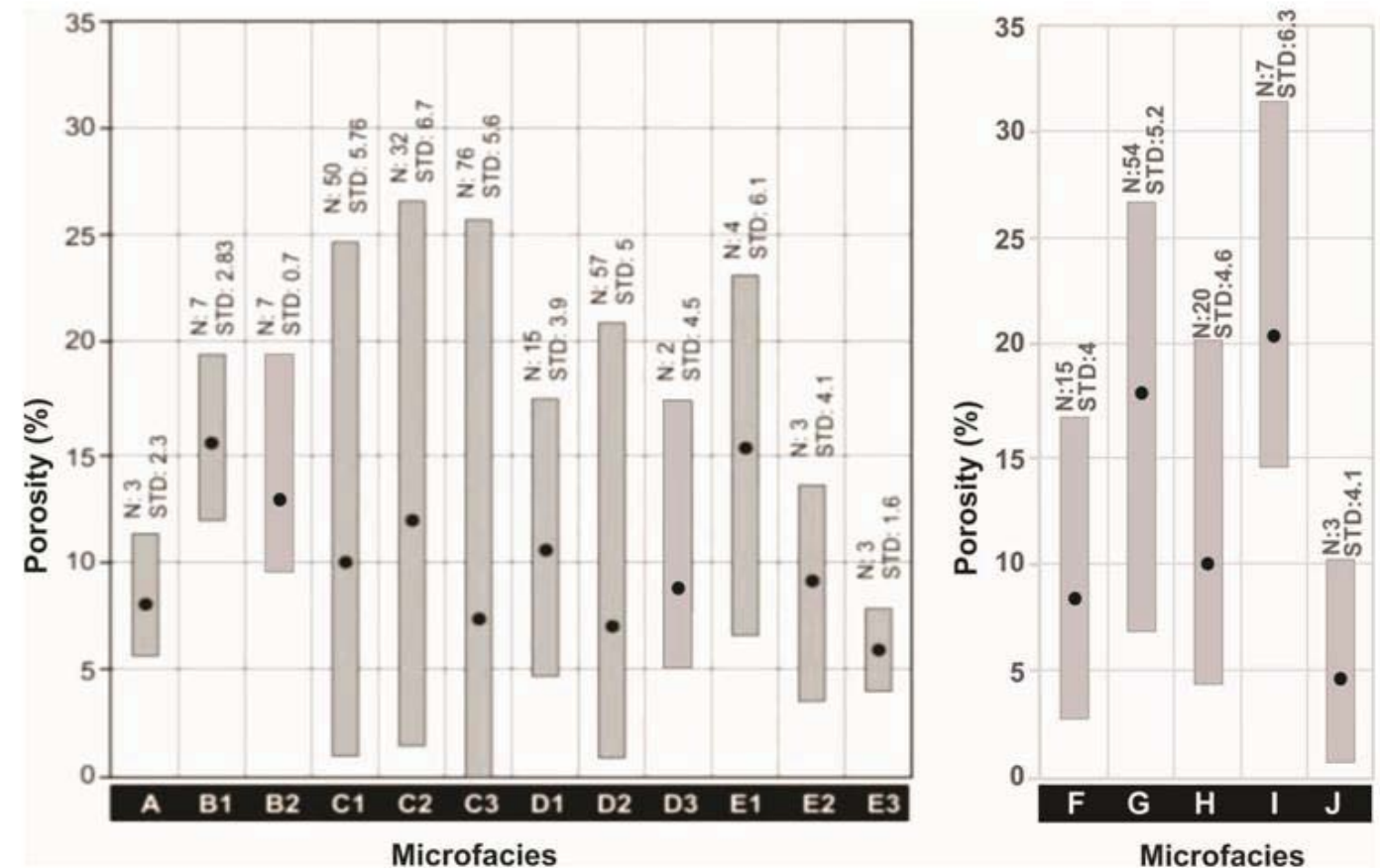

Figure 3 


\section{Figure}

Click here to download high resolution image

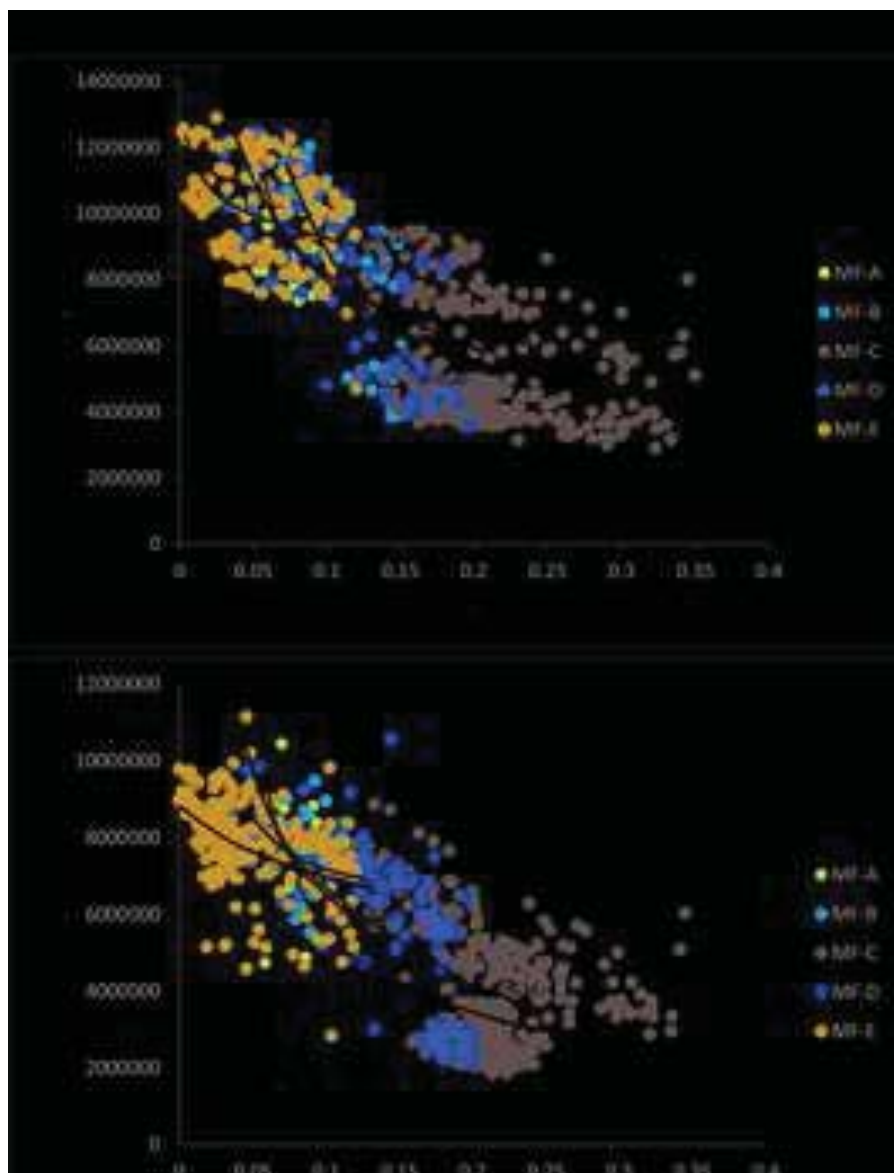

1
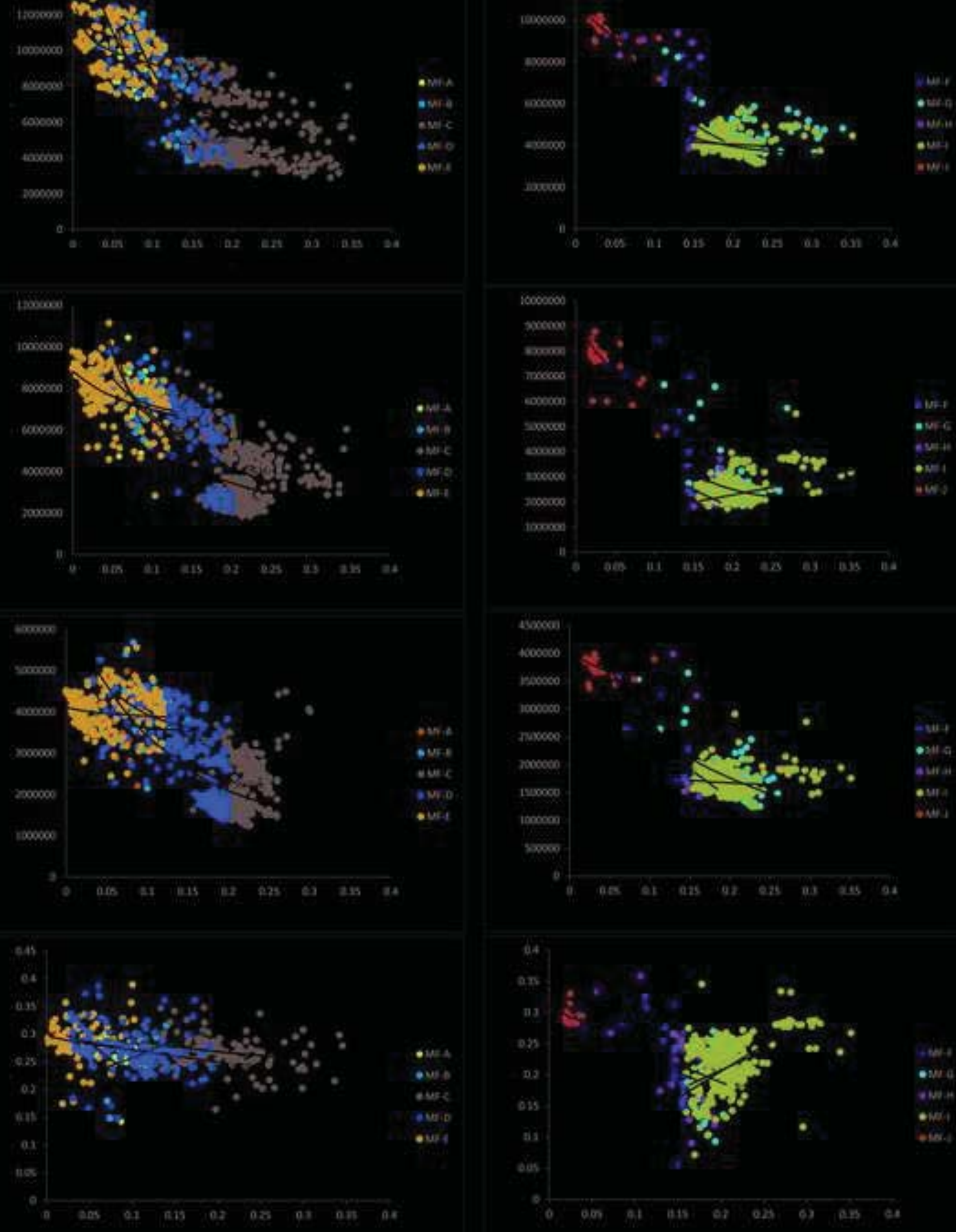


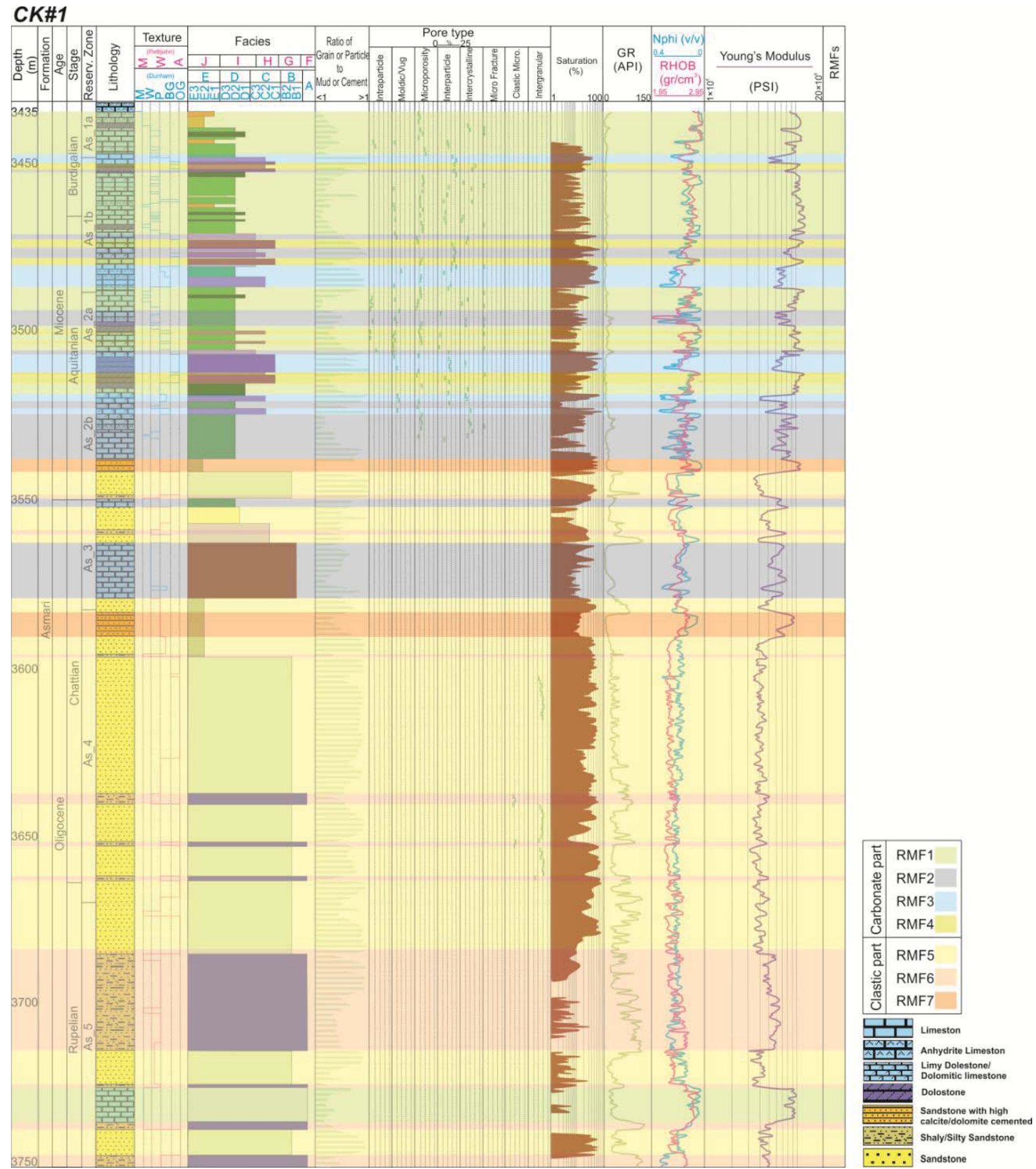

Figure 5 

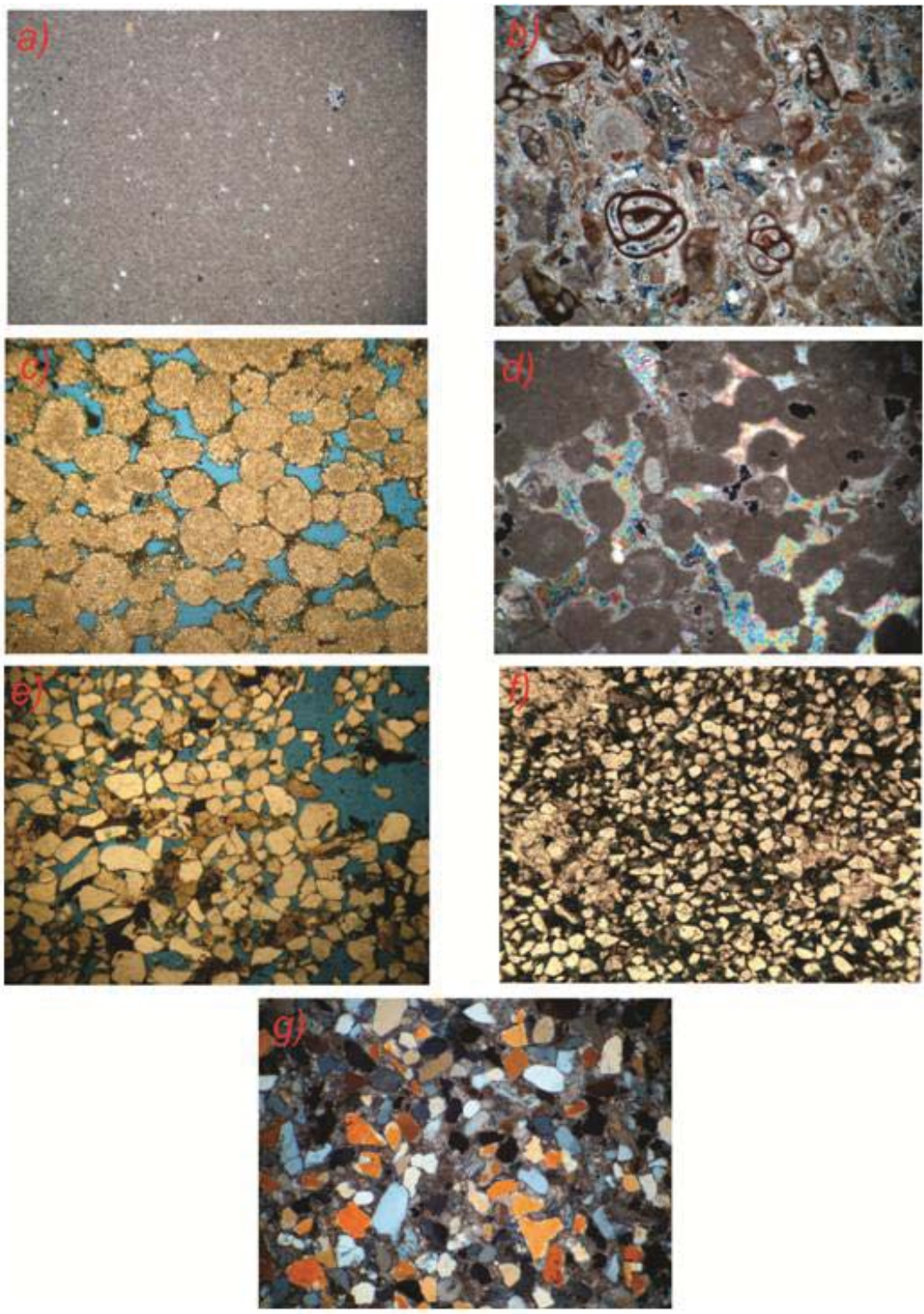

Figure 6 


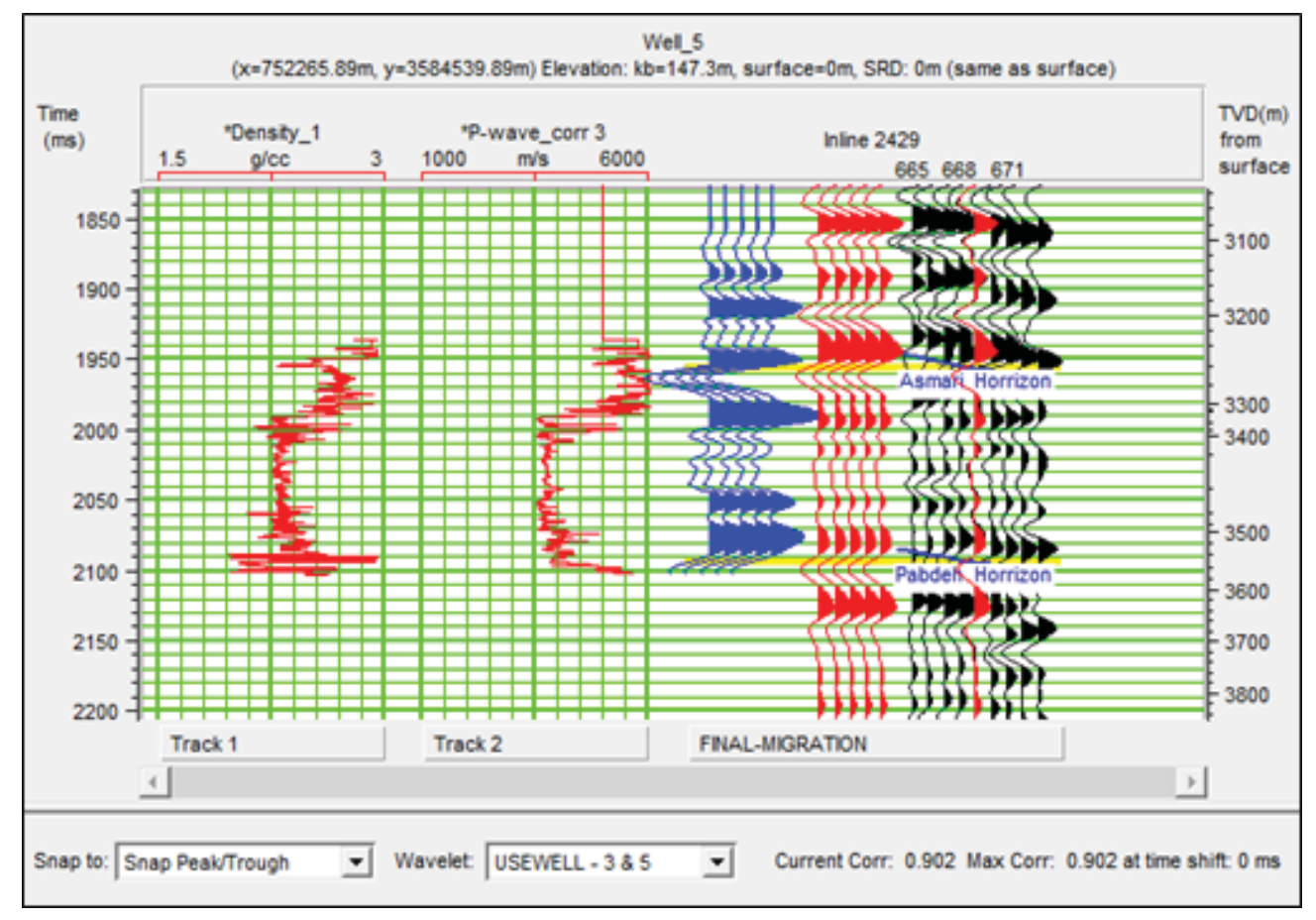

Figure 7 


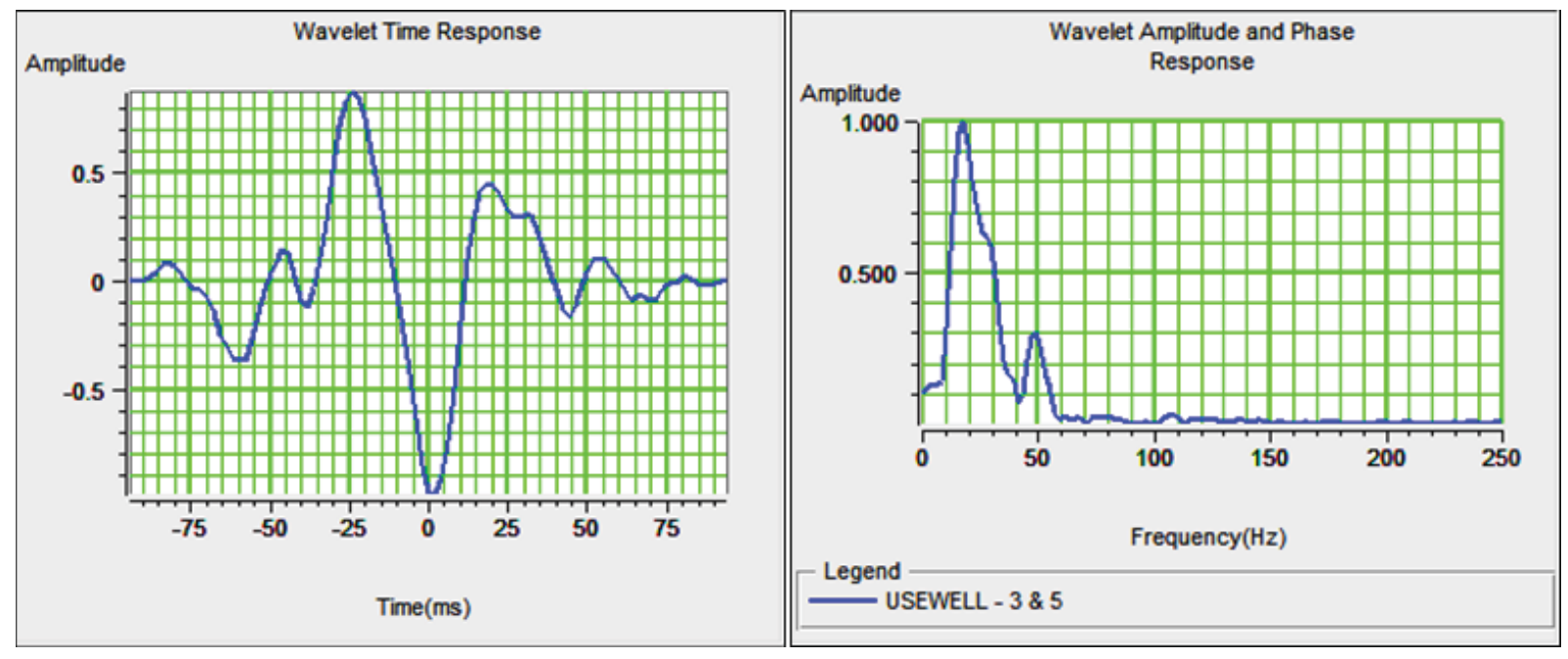

Figure 8 


\section{Figure}

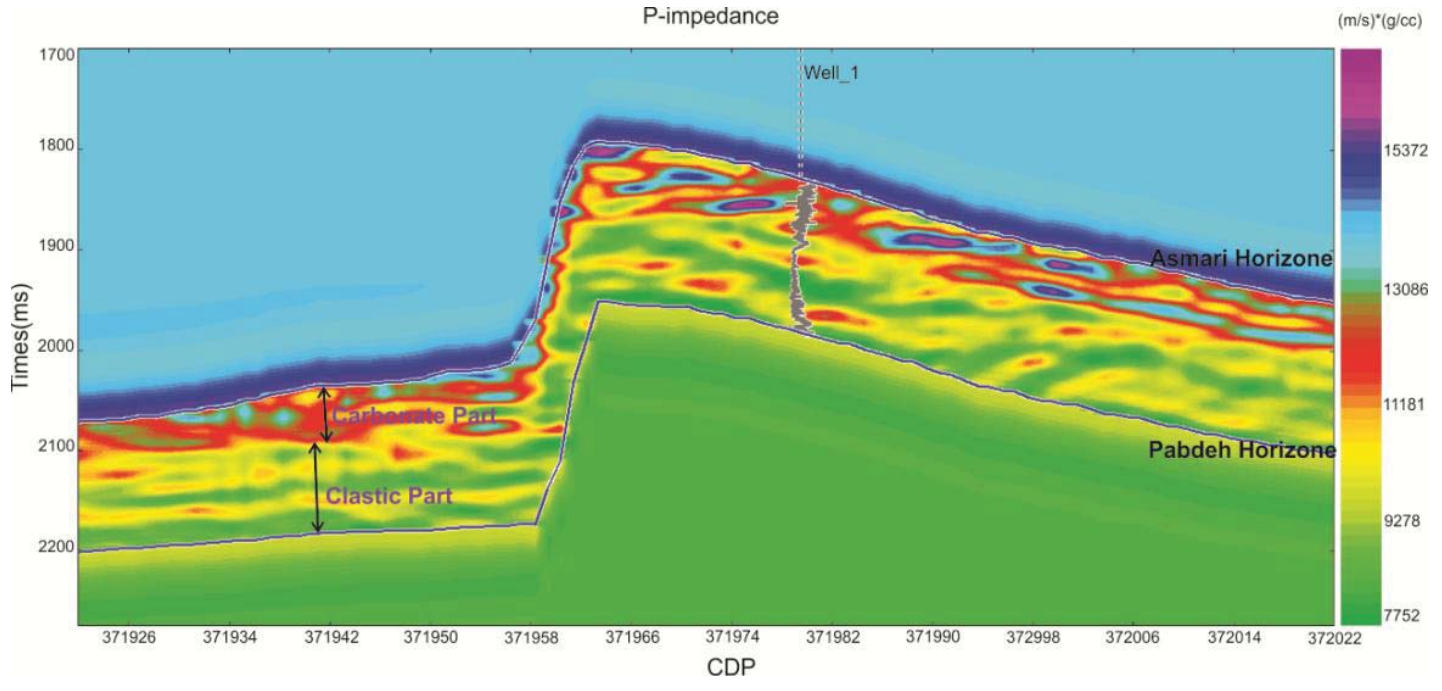

Figure 9 


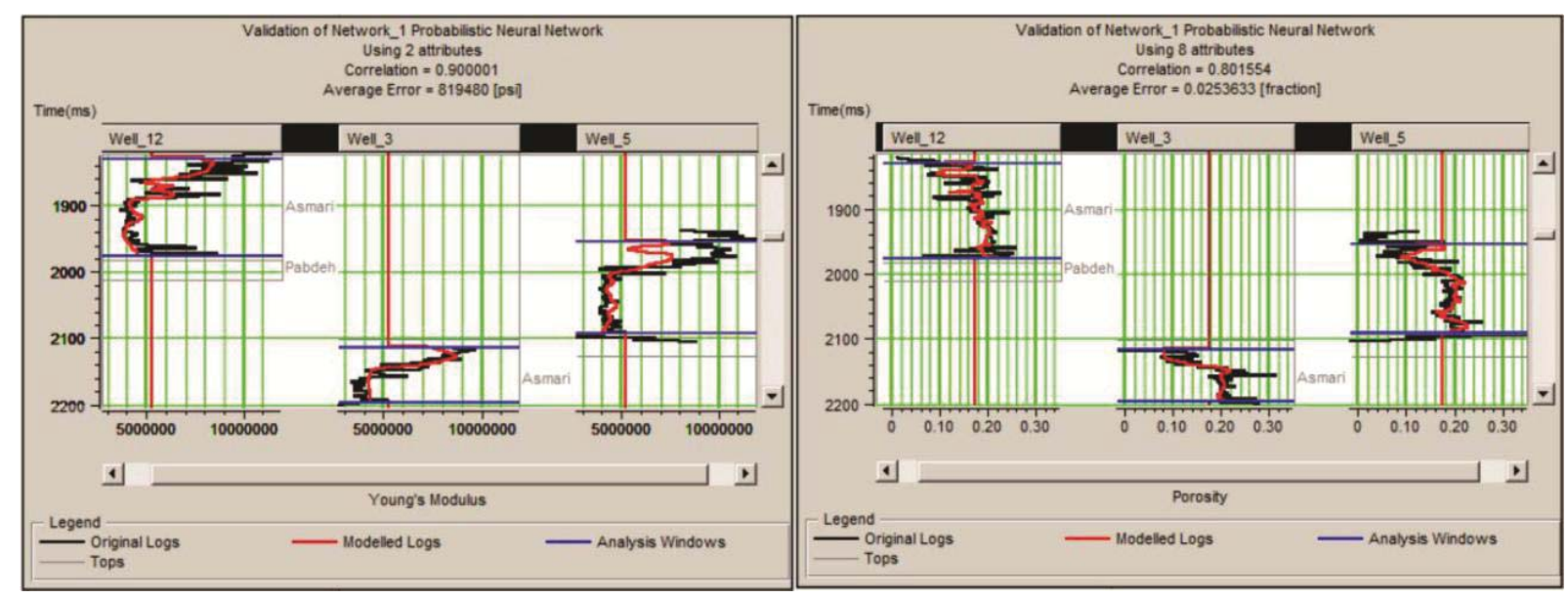

Figure 10 

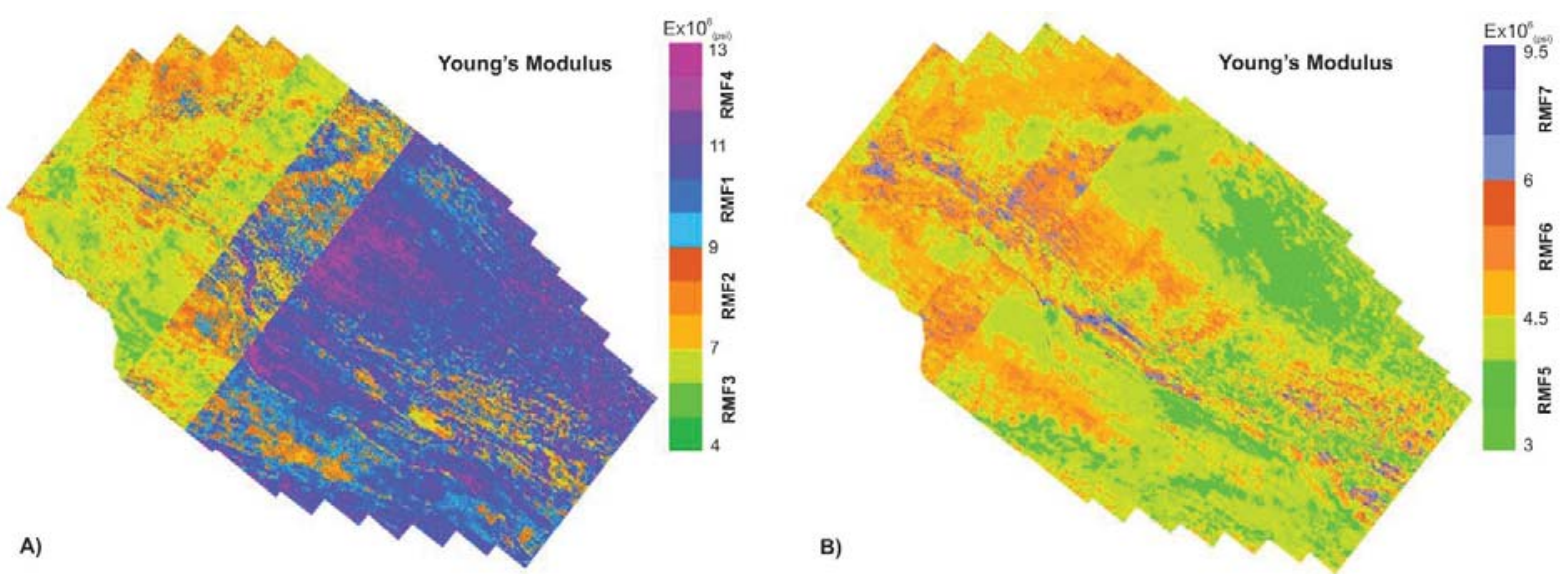

Figure 11 


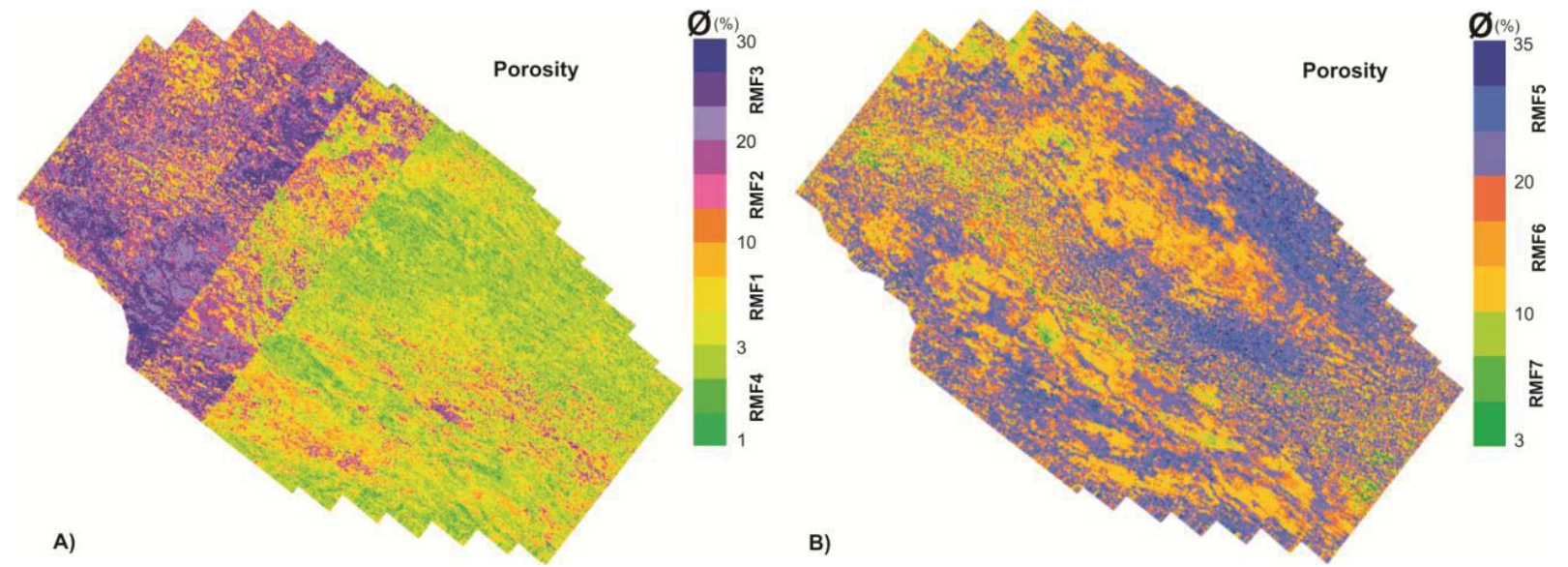

Figure 12 


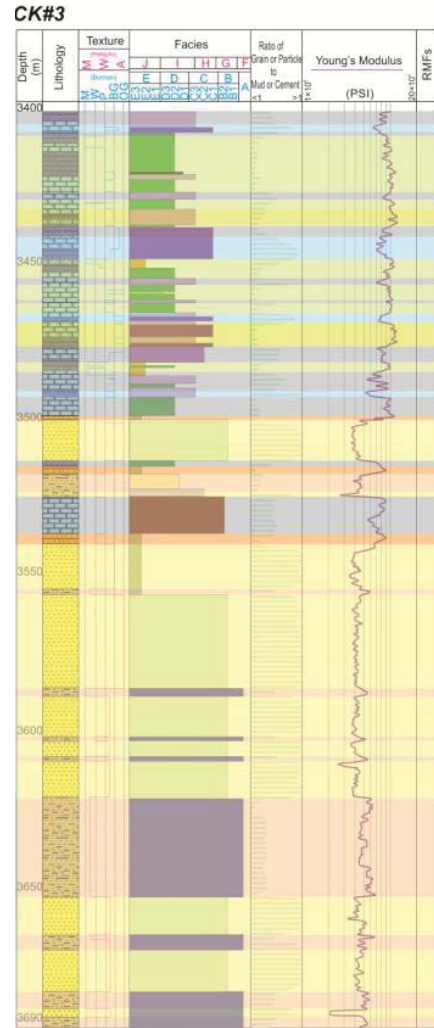

CK\#1
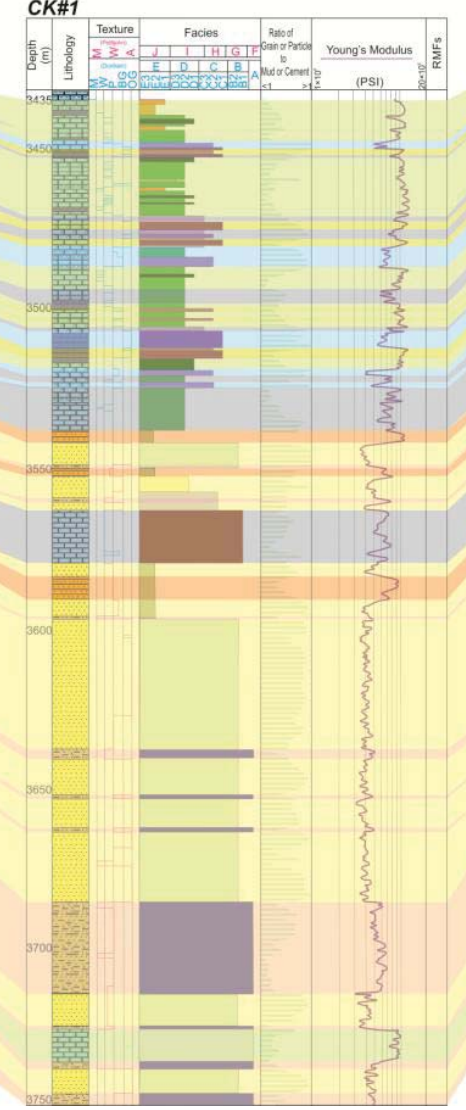

Figure 13

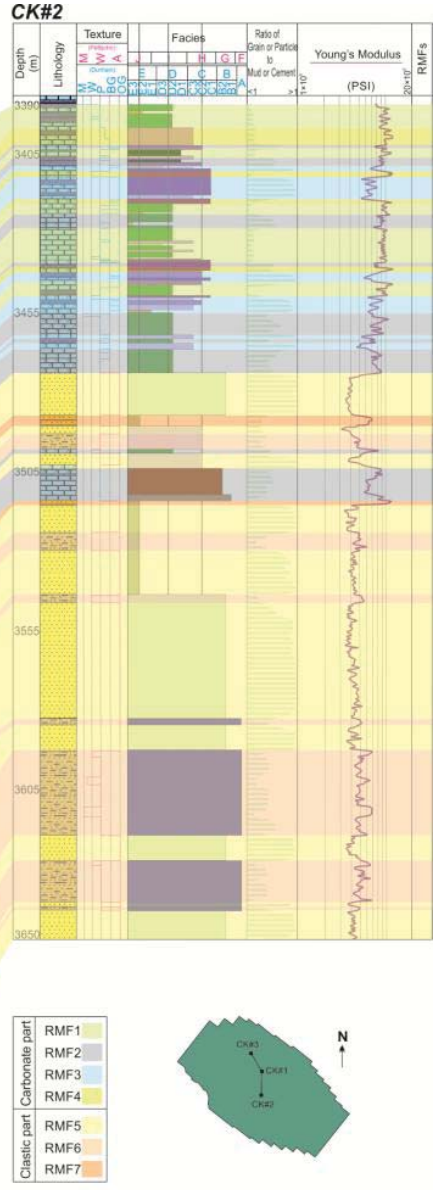

